\title{
Collecting Canadian Expeditionary Force (CEF) Badges and Medals Related to the Yukon During the First World War
}

\author{
Timothy J. Popp
}

Independent Historian

Abstract: I have been collecting Canadian militaria since the early 1970s. I now believe I have collected every known military badge associated with Yukon Territory military units. These include the Yukon Field Force (1898); the Dawson Rifles of Canada (1900); Boyle's Yukon Machine Gun Detachment (1914)—whose regimental badge was created by Jacoby Brothers in Vancouver; the Yukon Motor Machine Gun Battery (1915) - whose badges were created in England by Gaunt and Sons of London; the Yukon Infantry Company (1916) - whose unique badges were created by Jacoby and included a miniature miner's gold pan complete with a gold nugget at the base of the pan; the Pacific Coast Militia Rangers (1942); and the Yukon Regiment (1962). In my collection I also have examples of all medals that were awarded to Yukon residents. This article presents an overview of the badges worn on the uniforms of the military units that were raised in the Yukon for service with the Canadian Expeditionary Force. These badges are considered very rare to military CEF collectors, and seldom offered through an auction. The second part of the article covers the medals awarded to Yukon men who served in these units and, in particular, the many awards bestowed on Lt. Col. Joe Boyle. Military memorabilia is very important in the remembrance of the soldiers who represented the Yukon during the First World War. Along with a military file, the badges and medals worn by soldiers are a true connection with the past. This article is part of a special collection of papers originally presented at a conference on "The North and the First World War," held May 2016 in Whitehorse, Yukon.

The Northern Review 44 (2017): 163-208 


\section{Introduction}

I have been collecting Canadian militaria since the early 1970s. This started when, as a young lad growing up in Whitehorse, I joined the local army cadet corps. One day my Dad came home and tossed a handful of badges to me. From that day on I was hooked. When I started collecting I was interested in any type of Canadian military badge, but over time I became more specific. I now believe I have collected every known military badge associated with Yukon Territory military units. These include the Yukon Field Force (1898), Dawson Rifles of Canada (1900), Boyle's Yukon Machine Gun Detachment (1914), Yukon Motor Machine Gun Battery (1915), Yukon Infantry Company (1916), Pacific Coast Militia Rangers (1942), and the Yukon Regiment (1962). In my collection I also have examples of all medals that were awarded to Yukon residents.

Being a member of several militaria collecting societies, namely the Military Collectors Club of Canada, Canadian Society of Military Medals and Insignia, Calgary Military Historical Society, Orders and Medals Research Society (United Kingdom), and the Orders and Medals Insignia of America, I have gained a wealth of knowledge and contacts over the years. These collecting groups produce quarterly journals that have a worldwide distribution, and I have submitted several articles on my research in this area, including papers regarding my badges and Yukon individuals who served in the military. Additionally, some of these collecting societies hold annual general meetings with the opportunity to display personal artifacts. Several of my displays received awards.

\section{Canadian Expeditionary Force Military Badges}

The hat badge worn by most soldiers of the Canadian Expeditionary Force (CEF)-Canada's overseas contingentduring at least the first half of the First World War was the General List hat badge (Fig. 1). The basic design of the badge was a maple leaf that had an embossed crown located above a banner that enclosed the word Canada. This style of badge distinguished Canadian troops from other Commonwealth badges. Depending on manufacturer and time of manufacture, there were several variations on the theme of this badge.

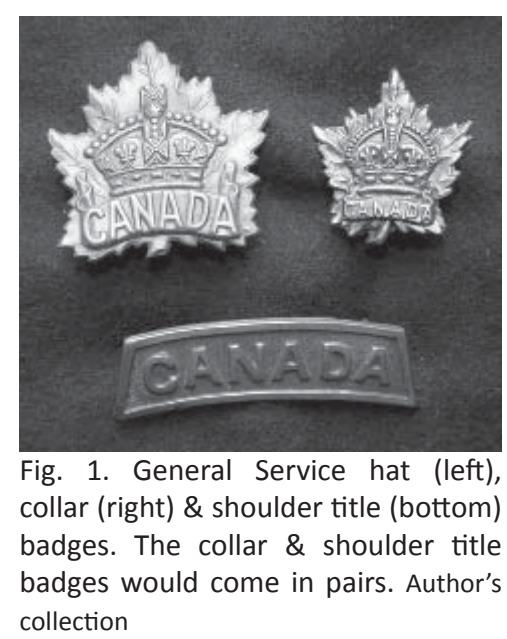


As the war proceeded, units began to wear badges of their own design. To gain authority to wear these unique badges, a military unit was required to develop a design for the badge. This normally came from suggestions within the ranks, but it could also be that the officer commanding had a concept in mind. Whichever way, a prototype design had to be drawn. Accompanying the design was an explanation, providing details of the symbols and their importance to the unit. Obviously, the allotted "Unit Number" or "Active Name" would have been known beforehand.

The design would then be forwarded to the quartermaster general of the Canadian militia for review, and if agreeable the design would go on to the minister of militia and defence for final approval. At any stage prior to final approval, the design could be returned to the unit for modification or it could be refused. If a unit badge was approved, there was no written general order indicating as such. Instead, a copy of the design was retained by the Department of Militia and Defence and a letter indicating approval was returned to the commanding officer. He would then place an order for the insignia with one of at least twenty-one known badge manufacturers, probably asking for competitive prices.

While hat badge designs did not have to be the same as collar badge designs, some CEF battalions used collar badges that were simply miniatures of the hat badge, thus saving the expense of creating a new design. An order would be placed with one manufacturer who would prepare artwork and dies, and strike samples for return to the unit for inspection and approval. Minor revisions would be made, the order placed, the badges struck and distributed accordingly, sometimes "at cost" to the recipients.

Replenishment orders often had variations of metal colours or finishes making the badge different from an earlier competitive manufacturer sample. Metal finishes included pickled (khaki), browning, black, antique, nickel plating, silver plating (or solid silver on occasion), and gilt. The latter two finishes were usually for officers. The composition of badges was bronze, copper, brass, white metal (an alloy usually of zinc and copper), and silver. The method of how the badge was attached to the clothing or uniform hats included lugs, folding tangs, slider, or brooch style pin. Sometimes badges were soldered directly to helmets.

\section{Jacoby Brothers Limited}

The first badge manufacturer to be contracted to produce insignia for a Yukon military unit was Jacoby Brothers Limited based in Vancouver (Fig. 2). Founded in 1909 by Alfred "Dick" Jacoby, this company produced 
mainly gold souvenirs, as well as commemorative and competitive award medals. In 1912 Dick's three brothers, Martin, Sigfried, and Henry joined the company. The company stayed in business until 1994 when the factory was finally closed. When war broke out in 1914, the company began producing hat, collar badges, and shoulder titles for British Columbia CEF units. They also produced the first Yukon CEF badges at the bequest of Joseph Whiteside Boyle, a prominent Yukon businessman and mining entrepreneur. Jacoby Brothers badges were usually identified on the back by the company name stamped in some fashion on an annealed maker's disc, or by a stamped representation of Aladdin's lamp, the company symbol (Fig. 3).

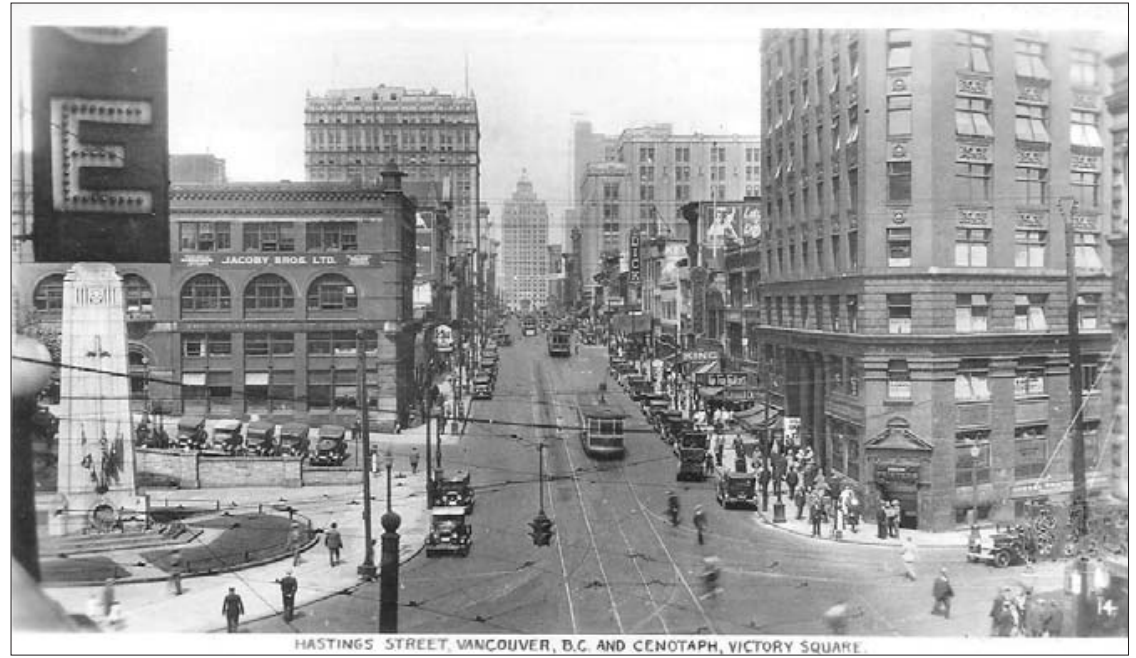

Fig. 2. Jacoby Brothers Ltd building beside Vancouver War Memorial on Hastings Street, 1922. Author's collection

Fig. 3. The monogram for Jacoby, Aladdin's lamp, was used on some badges instead of the embossing or maker's disc. www.trademarkia.com

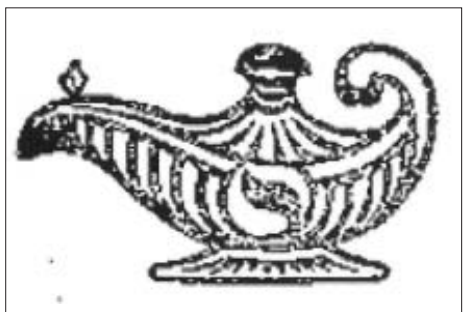




\section{Military Presence in the Yukon Territory Prior to the First World War}

\section{The Yukon Field Force}

Prior to the First World War there were very few organized military units in the Yukon. Between 1898 and 1900 the Yukon Field Force (YFF), comprised of Canadian permanent military forces, had been created to travel to the Klondike Gold Rush to assist the North-West Mounted Police in guarding the goldfields (Fig. 4.). One of the main reasons for the YFF going north was to show Canada's sovereignty over the region. There were fears that the United States government in Alaska would annex the area for the rich goldfields of the country. Other duties for the YFF included guarding gold shipments, participating in ceremonial parades, fighting fires, and assisting the NWMP in everyday duties. Of the 203 officers and enlisted men that comprised the YFF, forty continued with their military service into the First World War. Some of these men went on to have a distinguished career.

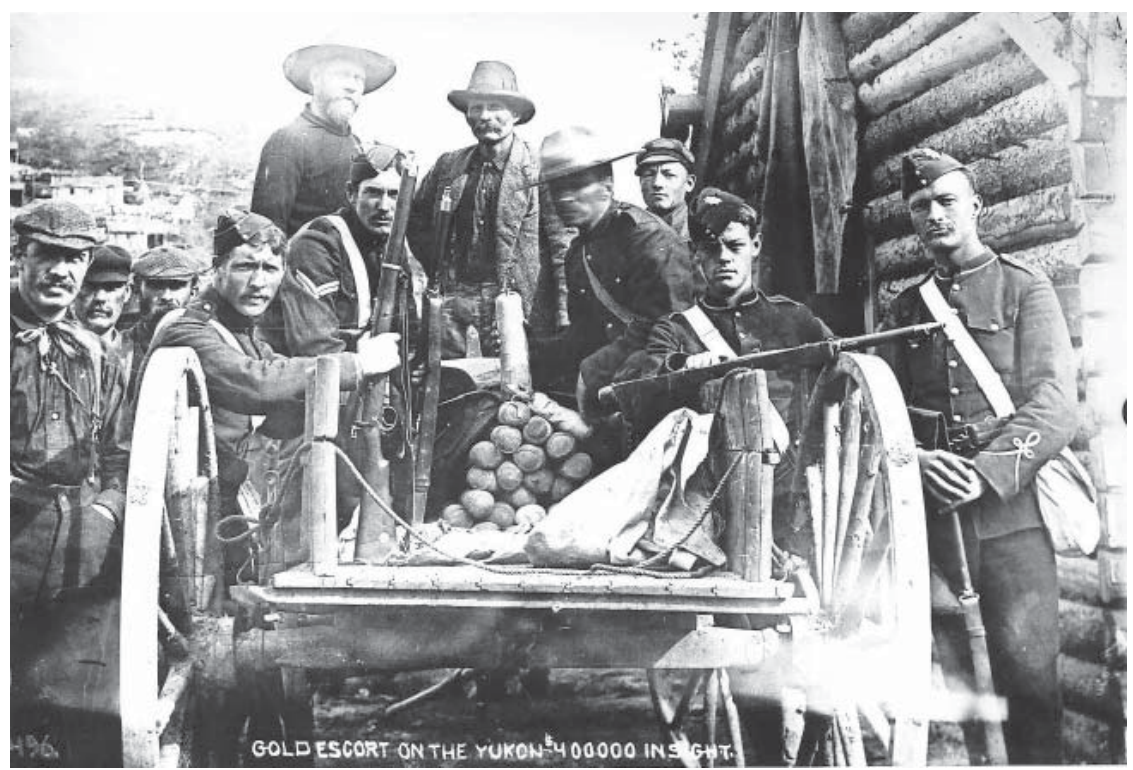

Fig. 4. Yukon Field Force "Gold escort on the Yukon $\$ 400,000$ in sight." The soldiers on the right wear the hat badge of the Royal Canadian Regiment. Alberta Archives P7118 


\section{The Dawson Rifles of Canada}

With the departure of the YFF in the summer of 1900, the Dawson Rifles of Canada (Fig 5.) was formed under the Non-Permanent Active Militia (NPAM). There was still fear of annexation by the United States and a new right-wing organization called the Order of the Midnight Sun was being investigated by the NWMP. A military presence, therefore, was still required. About four of the YFF members who took their release in the Klondike, hoping to stake a claim and strike it rich, joined this unit. The stores and weapons from the YFF were turned over to the NWMP and were utilized by the Dawson Rifles. The majority of the unit came from the men who worked on the dredges set up by big dredging companies, including a company run by Joe Boyle. They held rifle practices, ceremonial parades, and continued to assist with the protection of gold shipments. By 1905 there was no longer any need for a militia company and subsequently it folded.

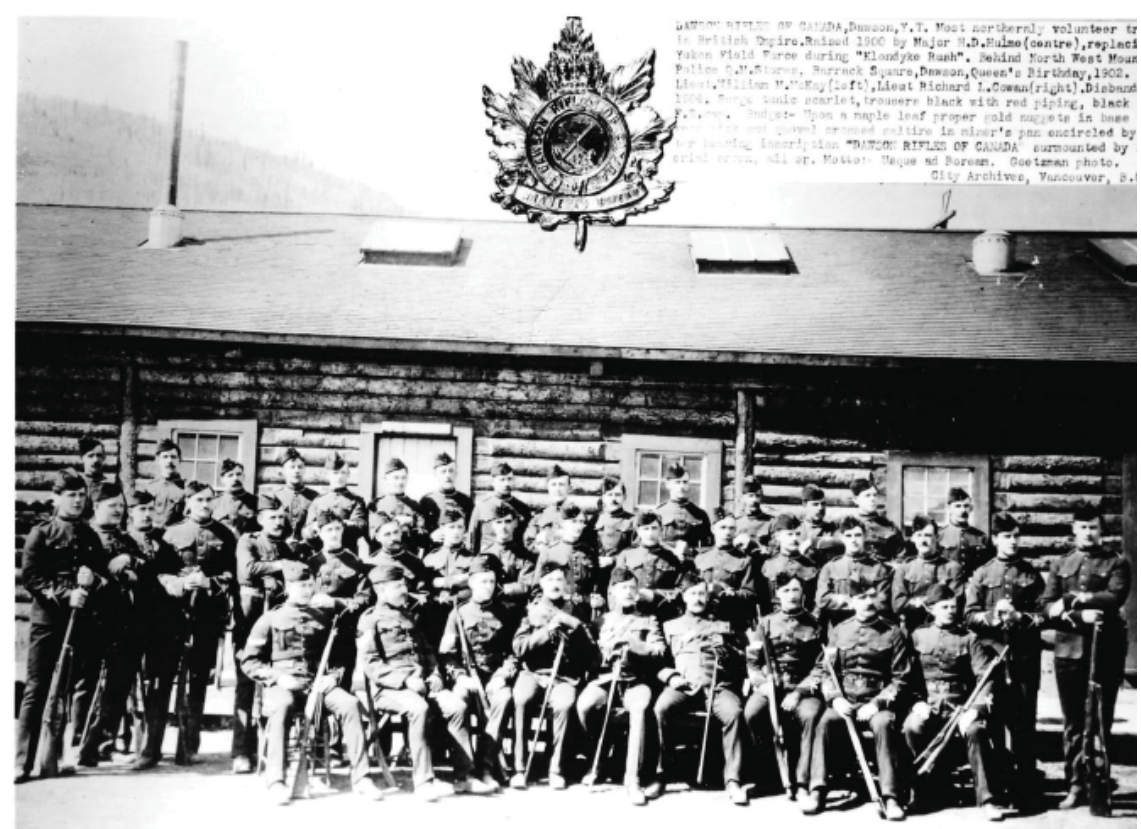

Fig. 5. Dawson Rifles of Canada. Some of these soldiers went into the CEF. The hat badge in the photo was simply stamped out and gilt plated. Yukon Archives Betts Collection \#7, $\mathrm{H}-227,81 / 80$ 


\section{Legion of Frontiersmen}

A somewhat paramilitary organization called the Legion of Frontiersmen (LoF) was formed in London, England in 1904 by a former NWMP and Boer War veteran. They were composed of former army veterans and men interested in fellowship who had a willingness to serve the British Empire in case of war. They existed throughout the British Empire with many units in Canada (Fig. 6). Three troops, or camps, were formed in Dawson, Carmacks, and Whitehorse, but the exact strength of each unit is unknown. It is known from Legion of Frontiersmen archives that they existed in Whitehorse around 1909. By 1912 a troop was formed in Dawson City, the commander being the local fire chief, Andy Hart. At the outbreak of the First Wold War, several Legion of Frontiersmen members enlisted for service either with a British or Canadian army unit.

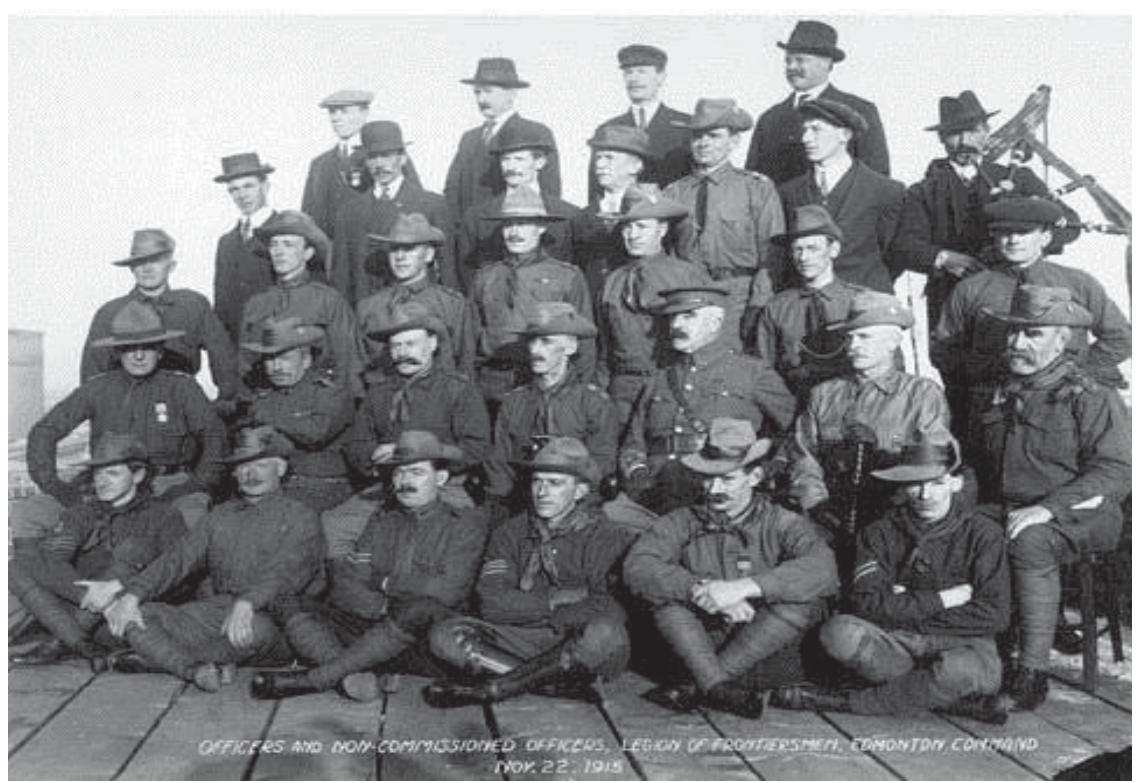

Fig. 6. Officers and Non-Commissioned Officers, Legion of Frontiersmen, Edmonton Command, 22 Nov 1915. Glenbow Archives ND-3-105 


\section{Yukon Canadian Expeditionary Force Units}

\section{Boyle's Yukon Machine Gun Detachment}

In late August 1914 the first Yukon unit raised was Boyle's Yukon Machine Gun Detachment, which was named after its founder, mining entrepreneur Joseph Whiteside Boyle (Fig. 7, p. 171). The fifty men in the unit were to be trained as machine gunners, as Boyle correctly foresaw this weapon as a new way to fight a war. Initially, the unit had no uniform when it was formed in Dawson City, but by the time they were ready to leave the Yukon they were adorned in khaki trousers, woollen shirts, mackinaw jackets, and Stetson hats. The unit left the territory on 8 October 1914. When they eventually arrived in Vancouver, British Columbia, the men were issued a proper uniform with the 2nd Canadian Mounted Rifles. A badge was needed for the unit and therefore a design was sought.

While in Vancouver, the unit had Jacoby produce their regimental badges. This was centred on the standard maple leaf design that can often be seen in other contemporary Canadian badges, such as the 2nd Canadian Mounted Rifles and the 29th (Vancouver) Battalion CEF. However, the first Yukon CEF hat and collar badges included a banner enclosing "Boyle's Yukon" with "MGD." (Machine Gun Detachment) below, then "Canada" in a banner at the very bottom (Figs. 8 \& 9). This is the only true Boyle CEF badge ever made that actually shows any connection to Joe Boyle. Even though other CEF military badge books suggest something different, there is no other Boyle CEF badge. The soldiers from Boyle's original unit wore another badge later on in the war, and it will be discussed later in this paper. That badge has no connection to Joe Boyle whatsoever.

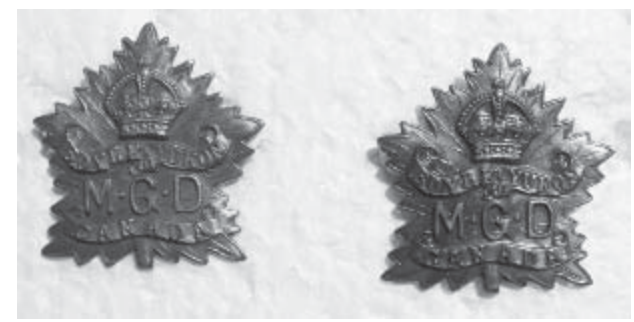

Fig. 8. Collar badges of Boyle's Yukon Machine Gun Detachment.

Author's collection

Fig. 9. Examples of the reverse of the Boyle's Yukon MGD collar badge. Embossing and lugs were used on the left collar badge whereas a maker's disc and brooch pin was used on the right badge. Author's collection

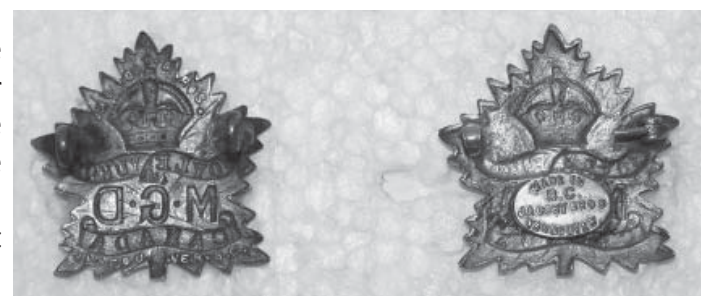




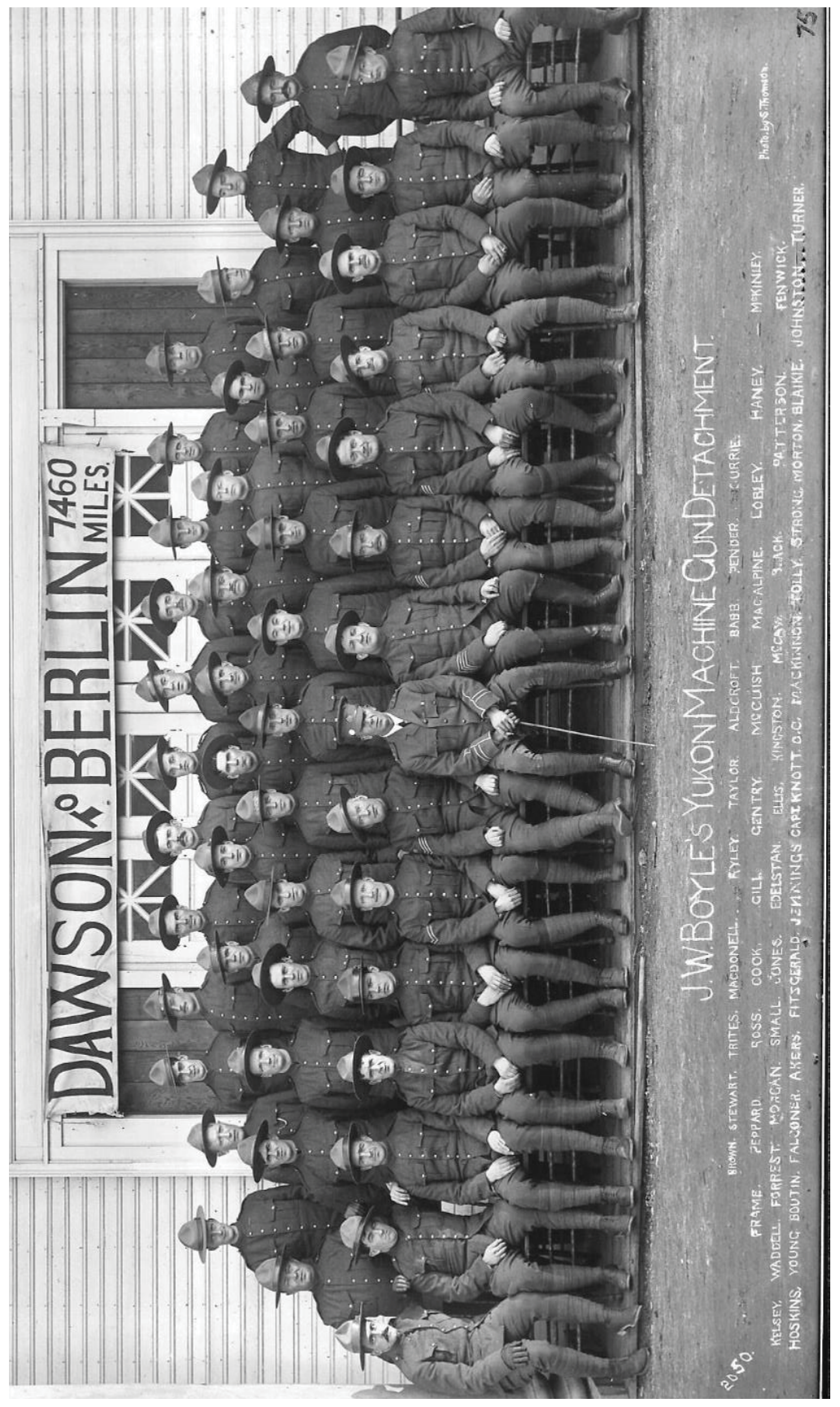

Fig. 7. J.W. Boyle's Yukon Machine Gun Detachment in Victoria, BC. The uniform is that of the 2 nd CMR. No badges had been issued yet. Vancouver Public Library \#6623 
Many examples of collar badges have also been seen with a jeweller's style brooch fastener as well as the more common flat lugs. A maker's disc is sometimes found affixed on the back or the edge may be embossed "Jacoby Bros. Vancouver B.C." The maker's disc has "Made In/B.C./Jacoby Bros/Vancouver." Most badges were made of copper with a gold wash or gilt finish while some were made of bronze. The collar badges measured $2.80 \mathrm{~cm} \times 2.96 \mathrm{~cm}$, which almost made it a square by height and width. The hat badge would be identical in design. While no hat badge has as yet been located its measurements would likely be $3.79 \mathrm{~cm} \times 3.80 \mathrm{~cm}$ thus making it almost square-sized like the collar badge. It was common practice in some CEF units to create a collar badge with the exact same design as the hat badge. This would save some expense using the same design.

The shoulder title badge, worn on the epaulets, was a slightly downward curved, roughly rectangular, bronze badge with the words "Yukon Territory" over "Canada" (Figs. 10 \& 11). The badge measured $1.62 \mathrm{~cm} \times 5.74 \mathrm{~cm}$. This too was made by Jacoby Bros.

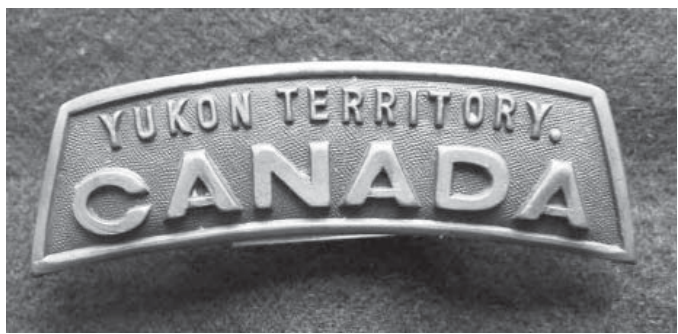

Fig. 10. Shoulder title badge worn by all three Yukon CEF units. Author's collection

Fig. 11. Three examples of the reverse of the Yukon Territory shoulder title badge. The top badge has "Jacoby Bros. Vancouver" embossing. Author's collection

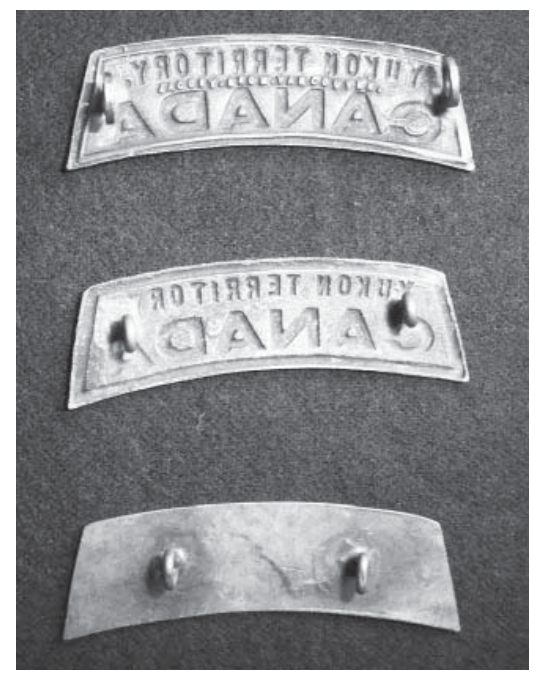


The officers and enlisted men, while stationed in the exhibition grounds at Vancouver, wore the first pattern badges of Boyle's Yukon Machine Gun Detachment. Before the unit set sail for overseas they were attached to the 2nd CMR and donned that unit's pattern of uniform. Figures 12 and 13 shows a member wearing the uniform of the 2nd CMR with clearly visible Boyle collar badges. This was how they looked until embarkation for England on the SS Megantic on 12 June 1915. The unit strength upon embarkation was two officers and forty-eight enlisted men. It was an imperative of Boyle that the unit be distinct and not absorbed by or dispersed into a larger unit.

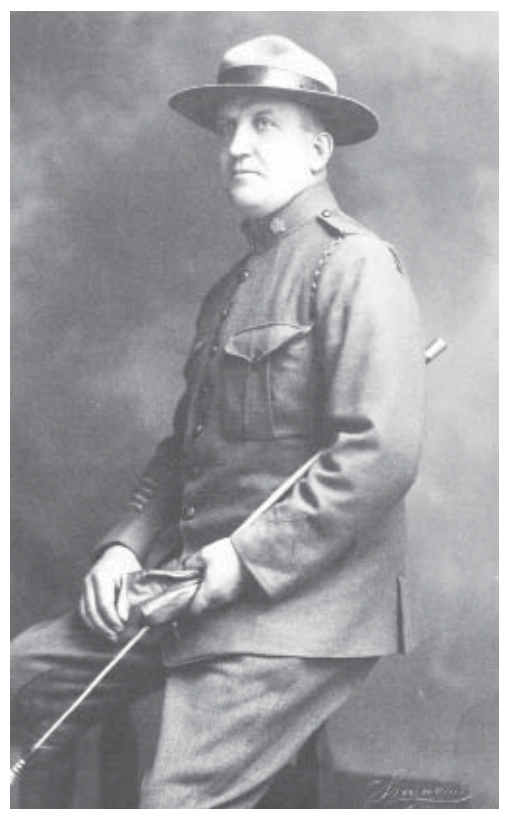

Fig. 12. Quartermaster Sergeant (QMS) James Mackinnon in $2^{\text {nd }} \mathrm{CMR}$ uniform with Boyle's Yukon MGD collar badges \& Yukon Territory shoulder titles. He wears no hat badge on the Stetson hat. Yukon Archives George Black collection \#81/107

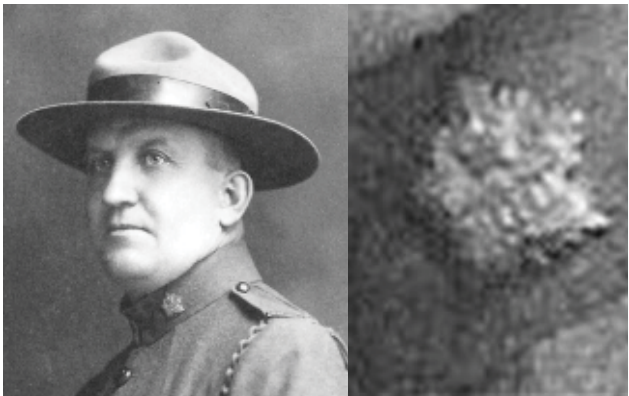

Fig. 13. Detail of Fig 12: QMS J. MacKinnon and the Boyle's Yukon MGD collar badge. 
On an interesting note, Joe Boyle was given the honorary rank of Lieutenant Colonel in the Canadian Militia for raising a machine gun unit. Boyle proudly wore a set of these badges on his uniform and, according to several biographies, they were reportedly made of solid gold from the creeks of the Klondike.

How many of the first style of Yukon CEF badges were made? There were at least fifty men in the unit and therefore there would have been that many hat badges with double the number of collar badges. Did the enlisted members wear the hat badge? It is not known if this was a common practice or if they even wore a hat badge on the distinctive Stetson hat. Officers of the unit wore the forage hat. Thus it stands to reason they would have a hat badge.

The unit went overseas without Boyle and when they arrived in England in July 1915 they were amalgamated with the Eaton's Motor Machine Gun Brigade and became No. 4 (Boyle) Battery. Their uniform changed by trading in the Stetson hat for a forage hat, and upon doing so they would now wear a hat badge.

A picture taken in England in the spring of 1915 shows a group of Yukoners from Boyle's unit with other machine gunners from what is believed to be Eaton's Machine Gun Battery (Fig. 14). In this photo the soldiers are wearing a forage hat and a maple leaf hat badge. Although the picture is not clear enough, the shape of this hat badge is very similar to the one QMS J. MacKinnon is wearing. Therefore, based on this 1915 photo, I believe that the Boyle's Yukon MGD hat badge does exist. Figures 15, 16, and 17 (page 176) show the Boyle's hat and collar badges being worn.

In all the years I have been collecting Yukon CEF badges, I have never come across a Boyle's Yukon MGD hat badge. I would consider this the "missing link" of all Yukon CEF badges and extremely rare.

A very interesting letter surfaced from Jacoby Brothers to Joe Boyle dated 18 February 1915. It indicates that changes could be made to the existing Boyle's Yukon MGD badges by simple modifications. Boyle was probably wanting the name of his unit to be changed to Boyle's Yukon Battery since Machine Gun Detachment was inappropriate. Jacoby quoted prices to have the badges made in bronze finish, silver oxidize, gold plating, or $10 \mathrm{~K}$ solid gold.

In my forty-five years of collecting I have never seen an example of the " $\mathrm{B}$ " design (Fig. 18, page 176). It is unknown if Boyle ever responded to Jacoby's letter so we can probably assume that this badge never came to be. Also, by this time Boyle's attention was focused on trying to get an active role in the war. The name of Boyle's unit was to change, as well as the hat badge. There was no longer any mention of his name. 


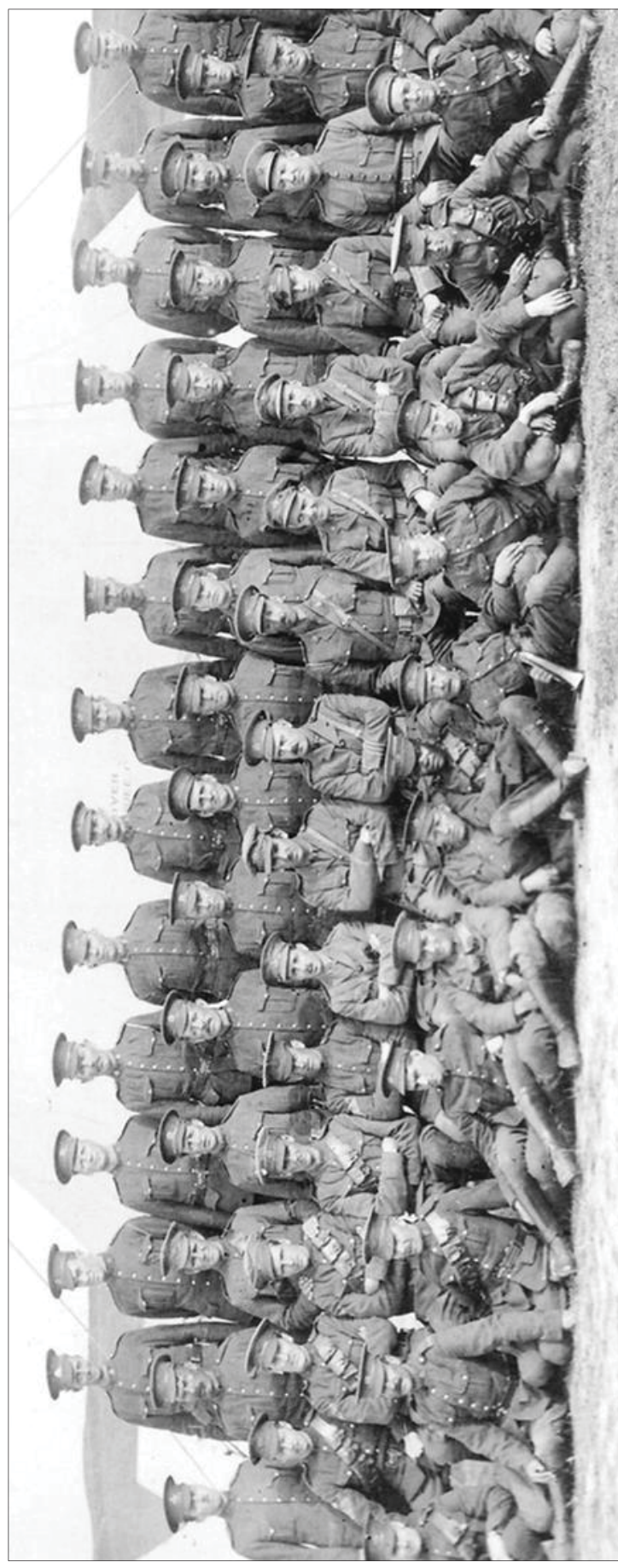

Fig. 14. Most of the soldiers in this 1915 photo taken in England are from Boyle's original unit. They are wearing Boyle's Yukon MGD badges. Archives of Ontario F229-308-02161-3 


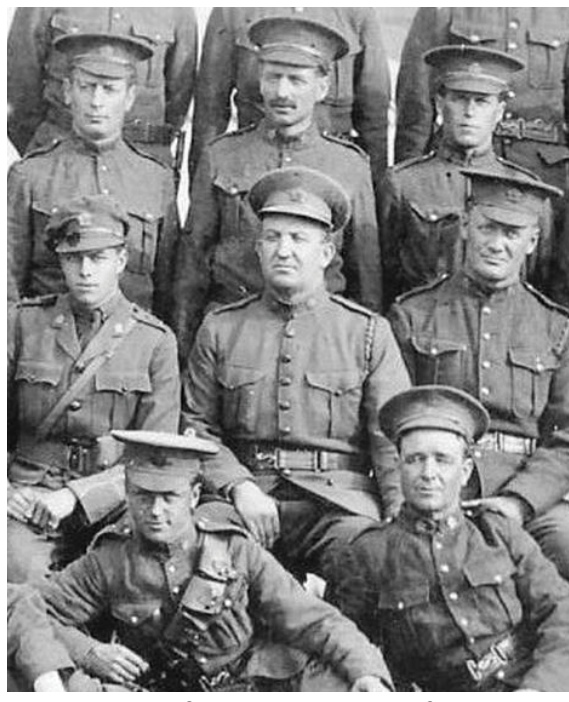

Fig. 15. Detail from Fig. 14. The officer seated left and the two soldiers, centre and right, are wearing the Boyle's Yukon MGD hat and collar badges. The soldier seated in the center is QMS J. MacKinnon.

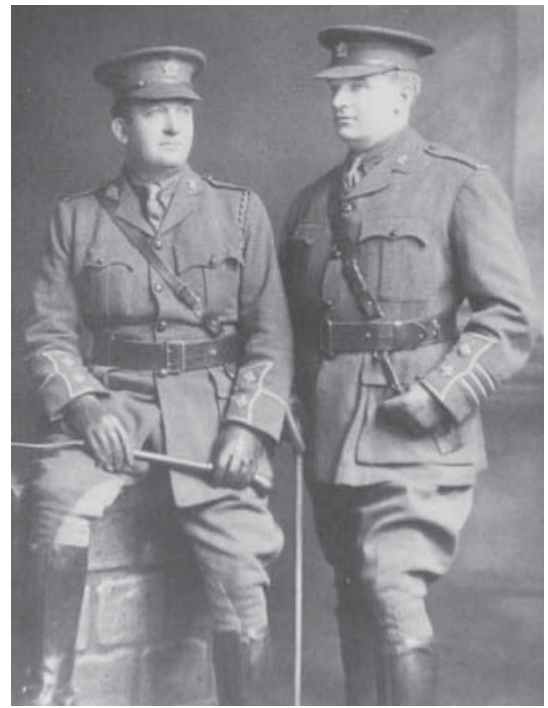

Fig. 16. Lieut. J. MacKinnon left \& Lt. Col. Joe Boyle right. Each are wearing the Boyle's MGD badges. Yukon Archives George Black collection

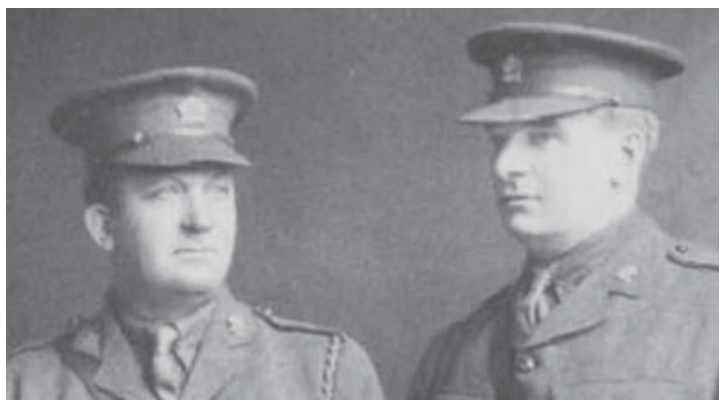

Fig. 17. Detail from Fig. 16 showing detail of the hat \& collar badges.

Fig. 18. A proposed collar, hat, and shoulder title badge design for Boyle's unit labelled "B." Author's collection

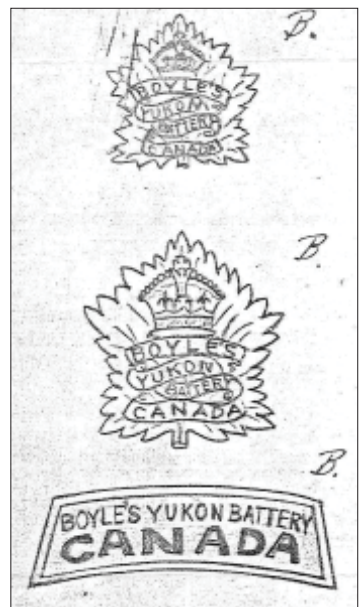


$67^{\text {th }}$ (Western Scots) Battalion CEF

Although this was not a Yukon raised unit, a special notation should be made for a small group of men who enlisted after the formation of Boyle's unit. In the fall of 1915 a group of Yukoners from Whitehorse enlisted with the $67^{\text {th }}$ (Western Scots) Battalion CEF as there was no other Yukon unit being formed at that time (Figs. 19 \& 20). Seventeen men took it upon themselves to enlist together and joined the $67^{\text {th }}$ Battalion in Victoria, BC. Initially an infantry battalion, it was later converted to a pioneer battalion. The battalion left Canada for overseas service in April 1916 and served with the $4^{\text {th }}$ Canadian Division in France and Belgium from August 1916 until the war's end. The battalion won battle honours for the Somme, Ancre Heights, Vimy,

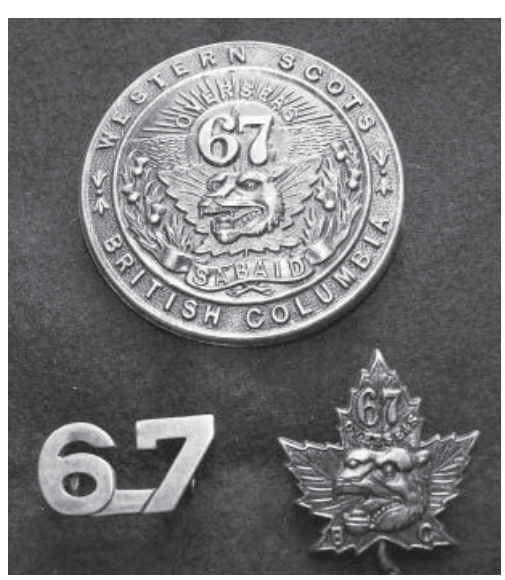

Fig. 19. The hat (top), collar (right) \& shoulder title (left) badges of the $67^{\text {th }}$ Battalion CEF (see Fig. 20.). The shoulder title badge would have been worn in conjunction with the universal "Canada" General Service shoulder title badge. Author's collection Arras, Arleux, France, and Flanders.

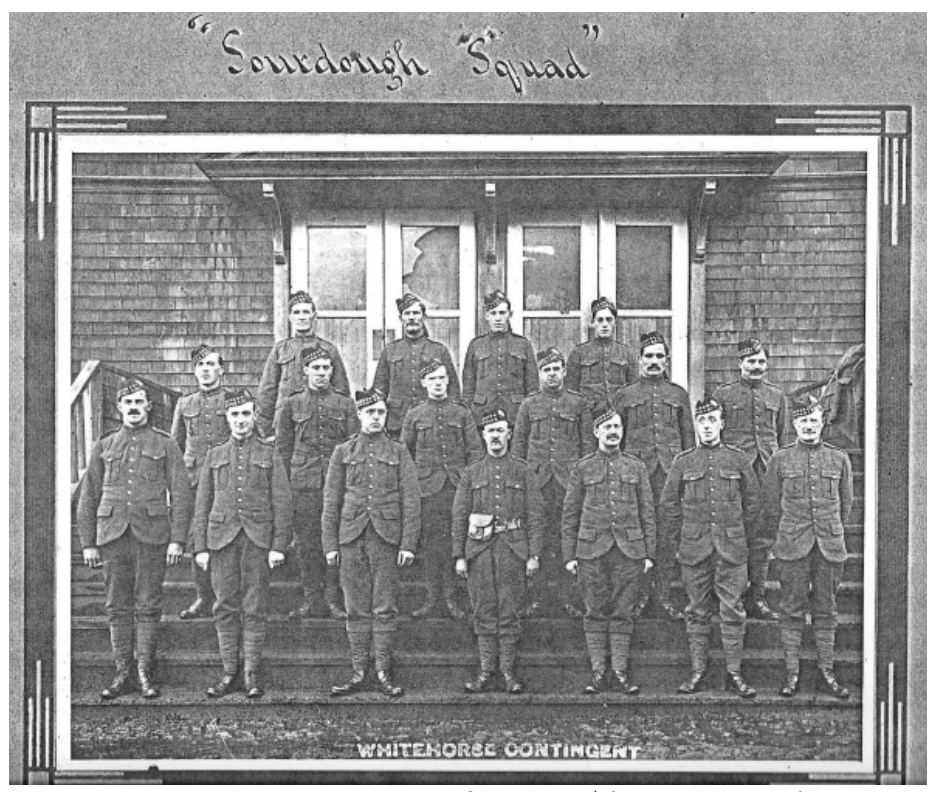

Fig. 20. The Whitehorse Contingent for the $67^{\text {th }}$ (Western Scots) Battalion

$\mathrm{CEF}$, Sourdough Squad. All soldiers have been identified. Author's collection 


\section{Yukon Infantry Company}

After the departure of Boyle's unit, many Yukoners in 1915 were left to enlist for overseas duty on their own accord. In 1916 the Yukon Infantry Company, a 226 man company, was raised by the then Commissioner of the Yukon Territory, George Black. The company trained on Vancouver Island near Victoria, BC. Like Boyle's unit, the machine gun also became their main training weapon.

Jacoby Brothers was again asked to make a set of badges. The design shape was similar to that of Boyle's Yukon Machine Gun Detachment badge, but instead had the words "Dawson" in a banner with "YT" underneath followed by "Canada" in a second banner all surmounted with a King's Crown (Figs. 21 \& 22). Many examples have been seen in bronze for enlisted men, with gilt finish for officer's badges. On the reverse of the badge is the embossed "Jacoby Bros. Vancouver B.C." along the edge, but these may also be found without the maker's name. The badge fasteners are seen as lugs in both wire and flat style, as well as folding tangs as seen for most of the Canadian CEF badges. The dimensions for this badge are $3.79 \mathrm{~cm} \times 3.80 \mathrm{~cm}$ (Fig. 23-26).

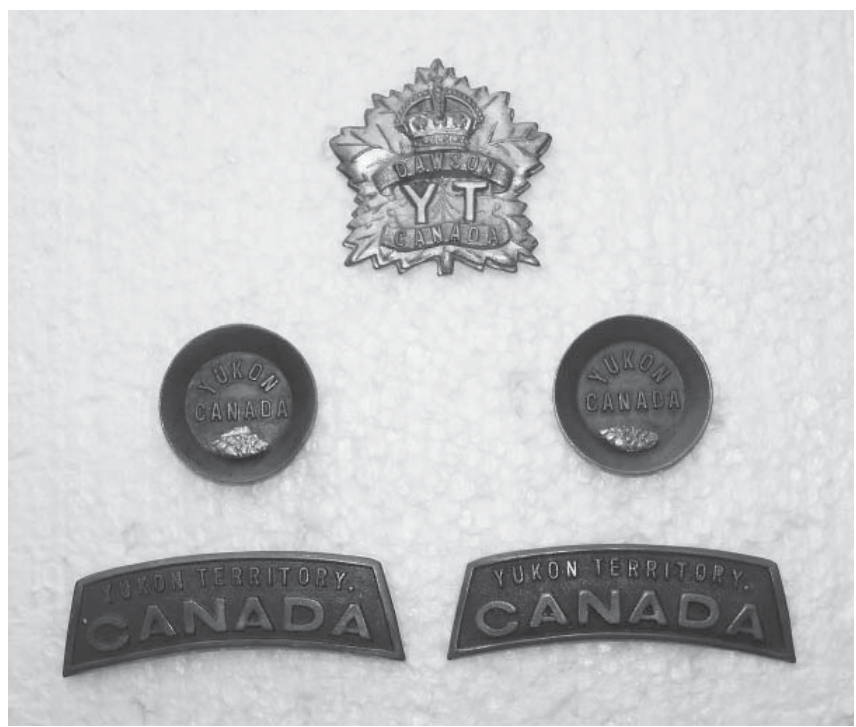

Fig. 21. Officer's hat badge, collar badges, and shoulder title of the Yukon Infantry Company. Author's collection 


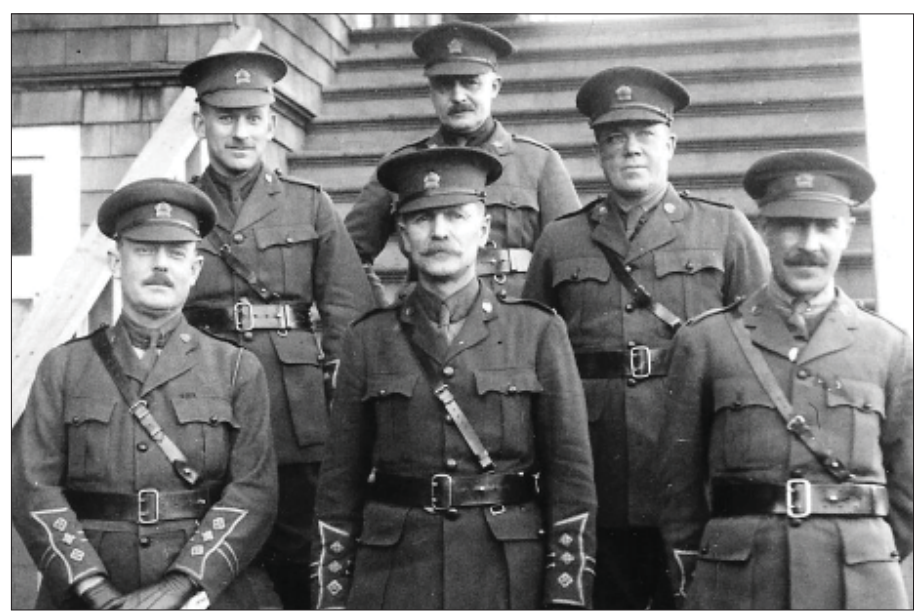

Fig. 22. Yukon Infantry Company officers in Victoria, BC. Front row from left: Capt. G. Hulme, Capt. G. Black, Lieut. F. Chute. Back row from left: Lieut. W. Radford, unknown, Lieut. J. Maclennan. All officers, except the unknown officer, wear the Yukon Infantry Company badges. Yukon Archives George Black collection \#80/107

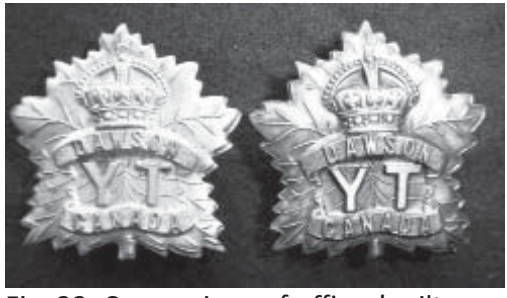

Fig. 23. Comparison of officer's gilt (left) and enlisted men's bronze (right) hat badges Yukon Infantry Company. Author's collection

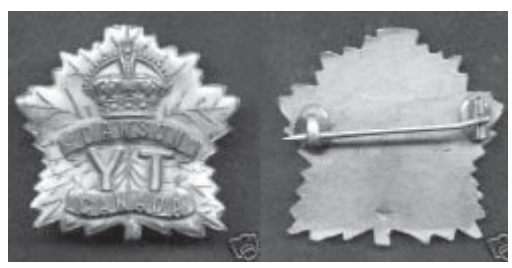

Fig. 25. Yukon Infantry Company hat badge and solid back reverse with brooch style pin. On the reverse image note the Jacoby Bros. Aladdin's Lamp monogram near the base. Photo from online source

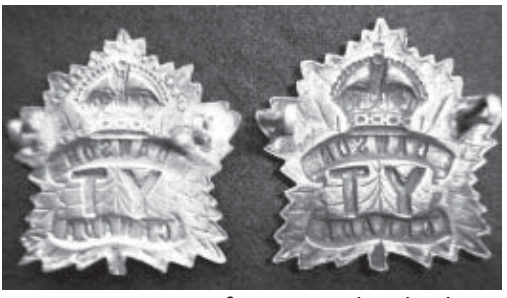

Fig. 24. Reverse of previous hat badges. Embossing on the left badge, "Jacoby Bros. Vancouver. Made In BC." The badge on the right was a later manufacture. Author's collection

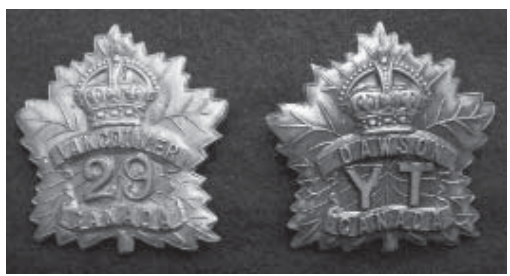

Fig. 26. Comparison in Jacoby-made hat badges. $29^{\text {th }}$ (Vancouver) Battalion, left, and the Yukon Infantry Company, right. Author's collection

The Northern Review 44 | 2017 
The collar badges are distinctive-a miniature miner's gold pan complete with "gold nuggets" at the base of the pan (Figs. 27 \& 28). These were not actual single gold nugget as some reports claim. The gold piece is to give an appearance of a pile of "nuggets" in the miner's pan. The gold nuggets have been chemically tested and are found to be probably $9 \mathrm{k}$ gold in metal content. The word "Yukon" is arched above "Canada" with no maker's name on the reverse of the badge. The badge itself, $2.64 \mathrm{~cm}$ in diameter, was made of a dull finished bronze. The nuggets are in bright gilt or gold. There is no official documentation to state which badge was issued to an enlisted man or officer. The nuggets are fastened in two ways. In the first method, two small holes were pre-drilled at the base of the pan. Each nugget had a small piece of copper wire attached to them that was fed through the holes and bent over securing it to the gold pan. The second method was to simply solder the nuggets to the base of the gold pan. The fasteners for the badge can be found with punched out style lugs, folding tangs, or a brooch pin fastener. The latter may have been used as a sweetheart pin.

The Yukon Infantry Company used the same style of shoulder title as Boyle's unit did with the badge being produced by Jacoby. While the Yukon Infantry Company was training in Vancouver, groups of men enlisted in Dawson and Whitehorse, raising the company to the proper unit strength. During this time, a group photo of the company was taken indicating temporary attachment to the $231^{\text {st }}$ Overseas Battalion CEF as " $\mathrm{D}$ " Company. A photo depicts a Yukon member wearing the hat badge of the Yukon Infantry Company and collars of the 231 ${ }^{\text {st }}$ (Seaforth Highlanders of Canada) Battalion CEF. The wearing of these unit's collar badges was only temporary until the miner's gold pan collar badge was produced and issued (Figs. 29 \& 30).

The Yukon Infantry Company was unique in another way. The officers and enlisted men were from more parts of the world than those in any other CEF unit. Almost all Commonwealth countries were represented, as well as the United States, Mexico, countries in Eastern Europe and Scandinavia, and even Tasmania.

As soon as the company was up to strength it set sail-with the now Captain George Black - on 24 January 1917 onboard the SS Canada from Halifax, Nova Scotia. With the company went George's wife Martha Louise Black as she was determined to be close to her husband and son, Lyman. Upon arrival in England, the Yukon Infantry Company continued training and was soon to be designated as the $17^{\text {th }}$ Machine Gun Company. Along with two other similar companies, as well as Eaton's Machine Gun Battery 
and the Yukon Motor Machine Gun Battery, they formed the nucleus of the $2^{\text {nd }}$ Canadian Motor Machine Gun Brigade. The badges of the Yukon Infantry Company were to change.
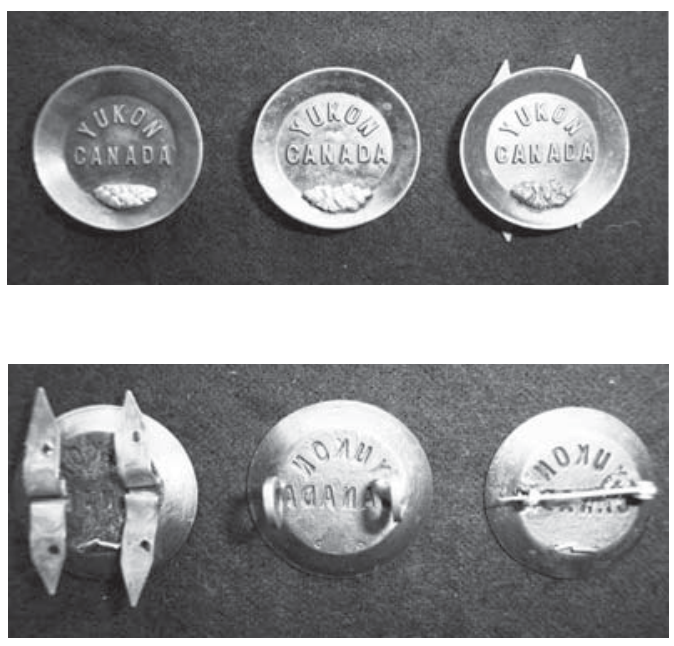

Fig. 27. Three examples of collar badges of the Yukon Infantry Company. There are slight variations to the "nuggets." The left and centre badges have low quality gold "nuggets" whereas the right badge "nuggets" have no gold quality at all. Author's collection

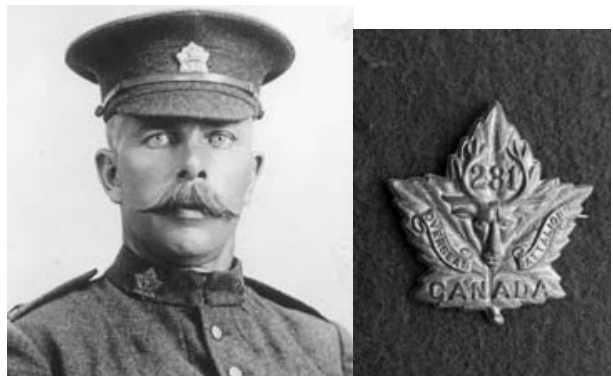

Fig. 29. Cpl R. Allen wearing the Yukon Infantry Company hat badge and collar badges of the $231^{\text {st }}$ Battalion CEF. Beside is an example of the $231^{\text {st }}$ Battalion CEF collar badge. Cpl Allen, Yukon Archives George Black collection \#80/107. Collar badge, author's collection
Fig. 28. The reverse of the collar badges for the Yukon Infantry Company, showing different styles of fasteners. The badge on the left has folding tangs, centre badge has lugs, and the right badge has a brooch pin. Author's collection

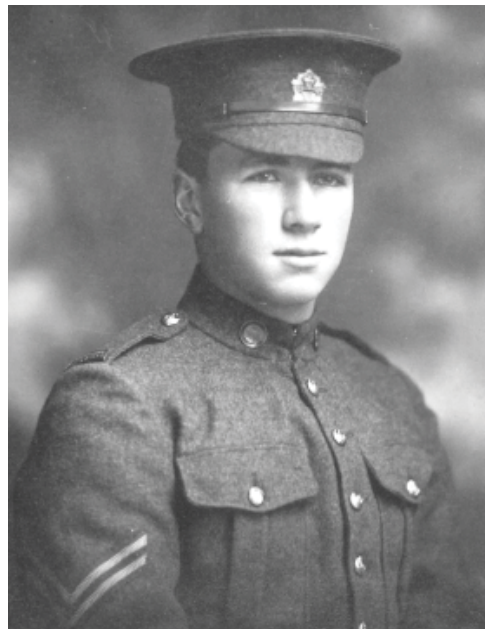

Fig. 30. Cpl Lyman Black, Yukon Infantry Company. The Yukon Infantry Company hat badge \& miner's gold pan collar badges are clearly visible. Yukon Archives George Black collection \#81/107 


\section{Yukon Motor Machine Gun Battery}

While Boyle's unit was training in southern England it acquired new hat and collar badges. Since Joe Boyle no longer had control of the unit, the unit was renamed the Yukon Motor Machine Gun Battery. J.R. Gaunt and Sons of London were commissioned to produce the next set of badges for the Yukoners. The badge was basic in design in that it was a pair of crossed machine guns surmounted by a King's crown (Fig. 31). Below the crossed machine guns was a banner enclosing the word "Canada." Nestled between the crossed machine guns and above the banner was a miner's gold pan with the initials "Y.T." At the base of the initials was a facsimile of "gold nuggets or nugget." The nuggets were chemically tested and found to be possibly $9 \mathrm{kt}$ gold or less.

There is a small hole at the base of the gold pan where the nugget has a wire attached to it. This was fed through the hole to secure it to the badge. The ends of the ribbon banner can be seen protruding past the machine gun grips on the collar badge, but on the hat badge the ribbon banner is clearly within the spade grips. This clearly illustrates the difference between hat and collar badges. The dimensions of the hat badge are 5.12 $\mathrm{cm} \times 4.78 \mathrm{~cm}$ while those of the collar badge are $3.77 \mathrm{~cm} \times 3.81 \mathrm{~cm}$.

It is interesting to note that the collar badge is a one-piece construction while the hat badge is of two-pieces. The hat badge is almost twice the size of the collar badge, but the gold pan and banner are the same size on both badges. This would suggest the lower portions of each badge were possibly made from the same dies. Hallmarking on the back of the collar indicates "Gaunt London" and the hat badge indicates "Gaunt London" as well as "J.R. Gaunt London." All collar badges are solid back while the hat badge has a slightly depressed solid back. Collar badges have three folding tangs or wire-type lugs, whereas the hat badge has only folding tangs. 
Fig. 31. The hat badge, collar badges, and shoulder title of the Yukon Motor Machine Gun Battery. Note the small "nugget" below the YT at the base of the miner's gold pan. Author's collection
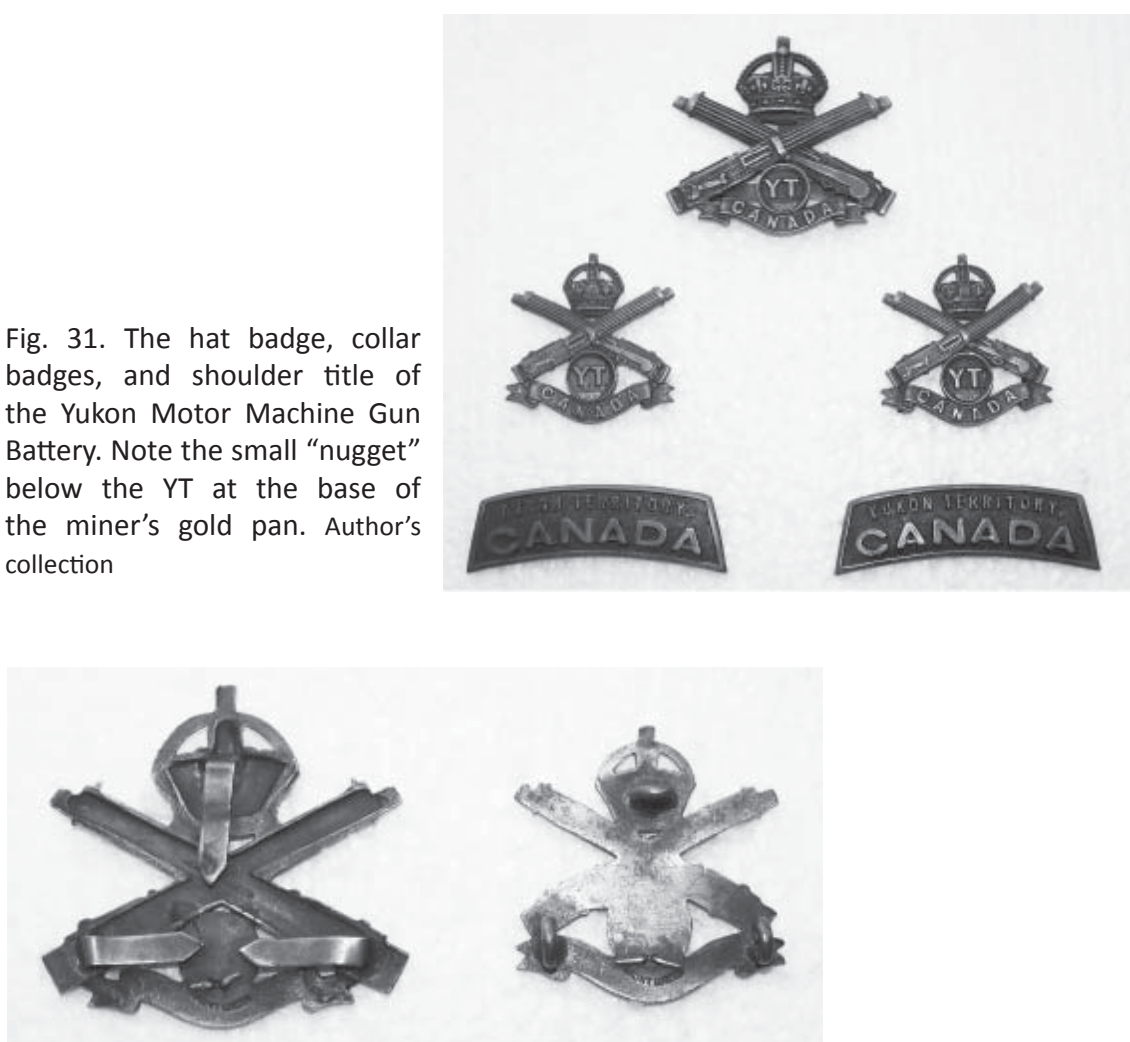

Fig. 32. Reverse of the hat badge (left) and collar badge (right) of the YMMGB. Note the hat badge is a two-piece construction, with the maker's name, JR Gaunt London. The small hole at the base of the badge to affix the "nugget" can be seen. Author's collection

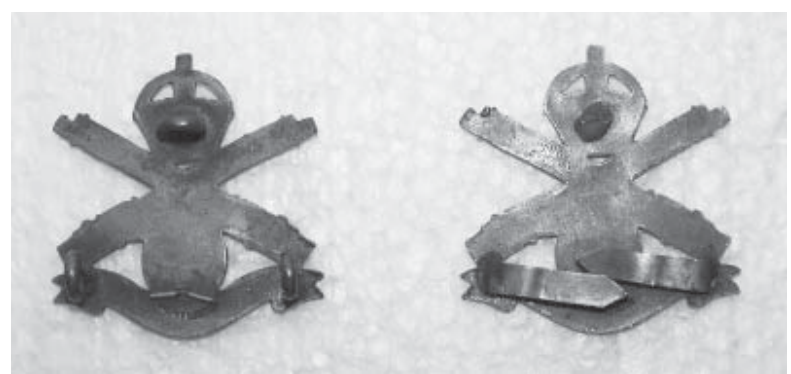

Fig. 33. Reverse of the collar badges of the YMMGB showing the one-piece construction. The badge on the left has lugs while the badge on the right has folding tangs. The small hole at the base of the badge to affix the "nugget" can be seen. Author's collection 


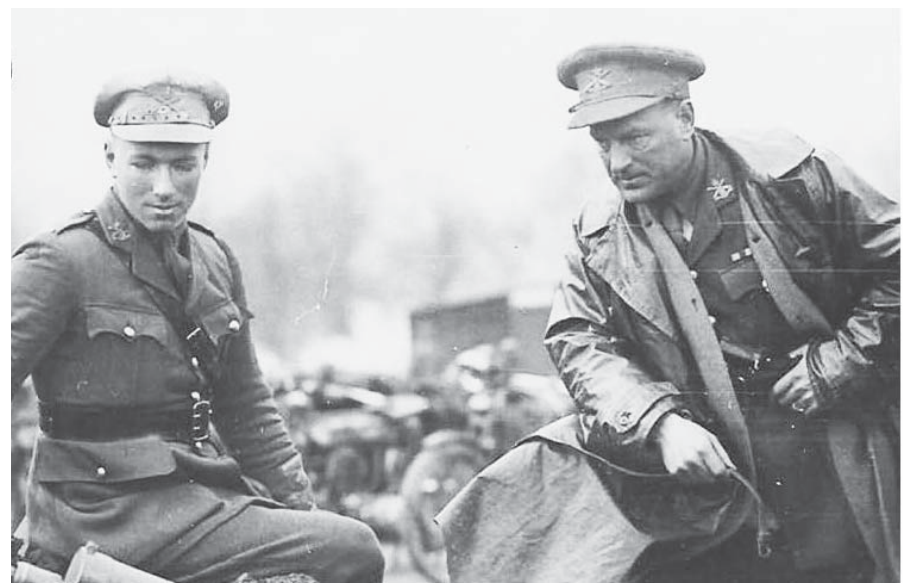

Fig. 34. Lieut. L. Black (left) and Capt. H. Meurling (right) wearing the Yukon Motor Machine GunBattery badges. Author's collection

Now, to dispel a myth which some CEF collectors tend to believe. During my years of research on this unit I discovered a photo of an elderly soldier wearing his uniform with the YMMGB collars correctly, but with a collar badge on his hat (Fig. 35). The collar badge is not a hat badge.

Let me explain Figure 35. The soldier is elderly and hence I believe this photo was taken near the end or after the war. He may have given his hat badge away at some time in his service and scrounged or borrowed another collar badge to wear as a hat badge. I have other photos in my collection of officers and noncommissioned officers from that period wearing the proper-sized hat badge on their hats.

This indicates that the hat badge was issued to all ranks and not just to a specific few. In all the information I have gathered on this unit from the Library \& Archives of Canada, nowhere does it state that the collar badge was to be worn as a hat badge by the enlisted men. Despite what is being said by auction houses, this

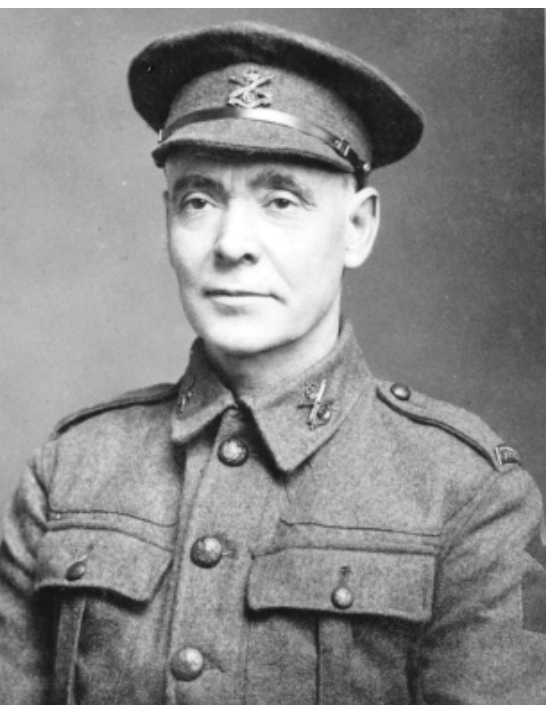

Fig. 35. An unidentified YMMGB soldier wearing a collar badge on his hat. This was not official practice in the unit. Note the divisional patches on his left sleeve. Photo from Yukon Archives George Black collection \#81/107 enhances the proof that collar badges were not officially worn as a hat badge. 
The Yukon Motor Machine Gun Battery was 'E' Battery of the 1st Canadian Motor Machine Gun Brigade (which also comprised Eaton's and Borden's Machine Gun units). In early June 1918, with the formation of the 2nd Canadian Motor Machine Gun Brigade, the Yukon Motor Machine Gun Battery was absorbed into the new unit and given the designation of 'A' Battery. It was during this time that the Yukon Infantry Company (17th Machine Gun Company) also became part of the 2nd Canadian Motor Machine Gun Brigade. They too adopted the Yukon MMG Battery badge. Eventually both Yukon units raised by Boyle and Black wore this badge as they were the nucleus of the 2nd Canadian Motor Machine Gun Brigade (Fig 36).

It must be made clear that the "Y.T. and crossed machine guns" badge is not Boyle's Yukon MG Detachment. Rather it is the Yukon Motor Machine Gun Battery. Many Yukoners did wear this badge and some of those were members of the original Boyle unit. Lt. Col. Joe Boyle never did wear this badge. Many photos of Boyle taken while he was overseas in Russia and Romania show him wearing only the maple leaf pattern badge of his original unit.

I know of only less than a handful of the Yukon MMGB hat badges in private collections. This badge is seldom seen at auctions or dealer's tables, thus making it one of the rarest of all the CEF badges to collect. At one auction, a silver copy of the YMMGB collar came up for sale. It is

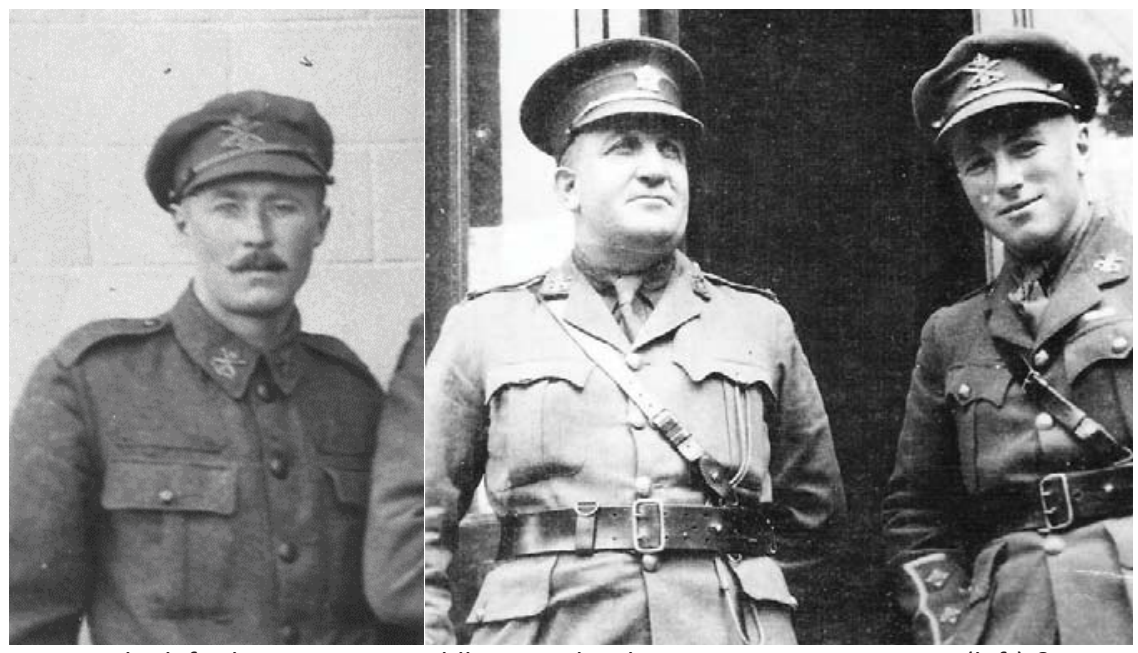

Fig. 36. The left photo is Pte. H. Oldham. Right photo is Lieut. J. McKinnon (left) \& Lieut. L. Black, MC. Both Oldham \& Black are wearing the hat badge \& collar badges of the YMMGB, while McKinnon wears the collar badges of the YMMGB, but the hat badge of the Yukon Infantry Company. Photo of Oldham from author's collection. Photo of McKinnon \& Black from Yukon Archives Waddington collection \#82/331-67 
probable that this is a reproduction badge. In 2010, a YMMGB hat badge was sold at an auction in Canada and commanded a very high hammer price of over $\$ 5,300$. The following year at an auction in England, a YMMGB collar badge was sold at an even higher price of over $\$ 7,300$ ! It was mistakenly listed as a hat badge, clearly demonstrating just how desirable these badges have become to collectors.

And what of some of the men who served in these Yukon units? Two notable soldiers from the Yukon Infantry Company were George and Lyman Black.

Corporal Lyman Black joined in August 1916 and rose quickly through the ranks and was promoted to lieutenant. At the age of nineteen years he was awarded the Military Cross for bravery in stemming a German cavalry charge. In Martha Black's autobiography, My Ninety Years, a soldier who was an eyewitness describes how this action took place:

During the night the infantry fell back without warning the machine gunners. At dawn we saw the enemy cavalry advancing four abreast, only 200 yards away. We opened up with the guns, point blank, with devastating effect. We held them up and stuck to it until the enemy opened up on both our flanks. It was getting hot under the collar so we hastily retreated about a quarter of a mile for a better position. While retreating two Yukoners fell, Sergeant Blaikie and Private Fisher. Lyman stopped to see if he could help them, but Blaikie was dead and Fisher, who was dying, urged him to save himself. As the Huns were right on our heels he had to run for it. He then remounted the one remaining gun and opened up on them. For 12 days he was fighting like this, and how he ever came through without a scratch is a marvel.

Lieutenant Lyman Black, on a motorbike, led the 2nd CMMGB in the procession in the final victory parade held in Mons at the end of the war (Fig. 37). Black continued to serve in the military and later transferred to the PPCLI. He died in a car accident near Ottawa in 1936.

Captain George Black was wounded in 1918 and at the end of the war was employed as defence counsel for about twenty-five soldiers who were facing court martial offences stemming from the riots at Kimmel Park, England. George Black and another fellow officer managed to get twenty of the soldiers acquitted, while the other four received light sentences. One, a serving Russian in a Canadian unit, was charged with hitting an officer over the head with a $2 \times 4$ board. He was deported back to Russia. 


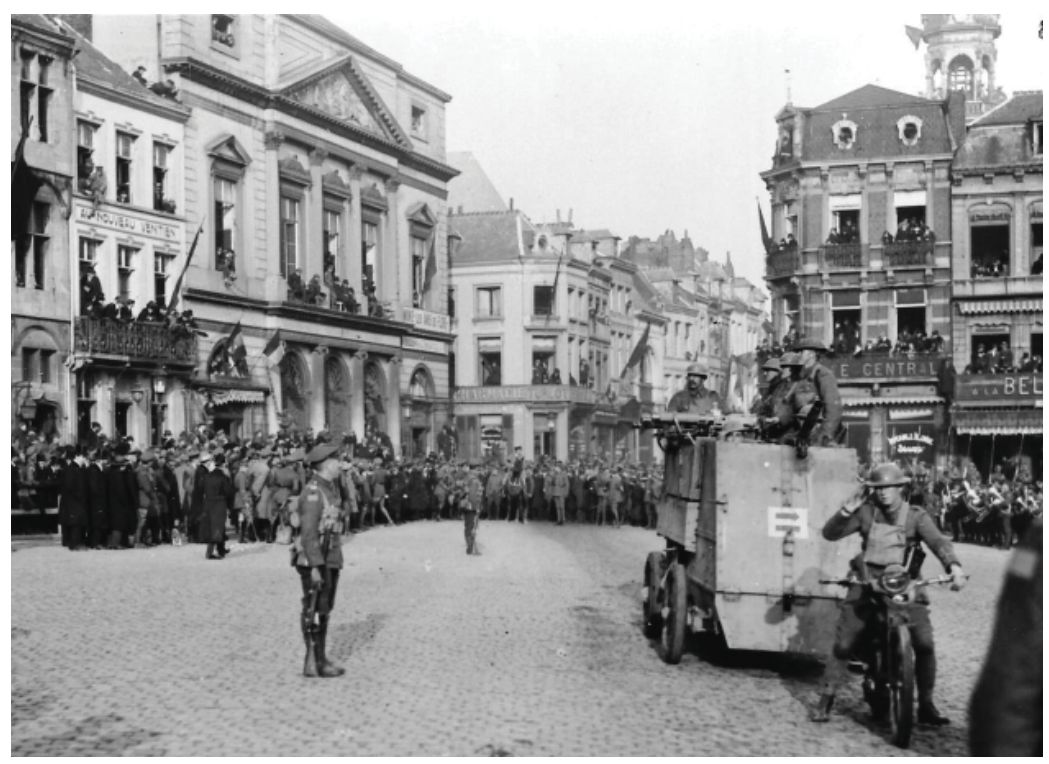

Fig. 37. Victory parade in Mons, Belgium, 11 Nov 1918. Lieut. L. Black, MC on motorbike ahead of the armoured car. National Archives of Canada \#PA 3590

Martha Black, George's wife, had accompanied her husband and son overseas and stayed in an apartment in London. She kept herself busy by giving lectures about the Yukon to Londoners and by administering the Yukon Comfort Fund, which was sponsored by the Dawson City branch of the Imperial Order Daughters of the Empire. Whenever some of the Yukon troops were on leave, they would stop in to say hello from time to time. This would be when the Yukon Comfort Fund was utilized. Mrs. Black would, on occasion, try to visit with George and Lyman on the base and was lucky at times to have a dinner with them. In her autobiography, she notes that during the Christmas of 1917 the YMMGB presented her with a unit badge made of gold (Fig. 38).

This particular badge came up for auction some time ago and it is suspected that this may be the very badge that was presented to Mrs. Black. Unfortunately, the auction lot item did not list the provenance of the badge nor was there any personalized engraving on the reverse. The current owner of this badge is unknown at this time.

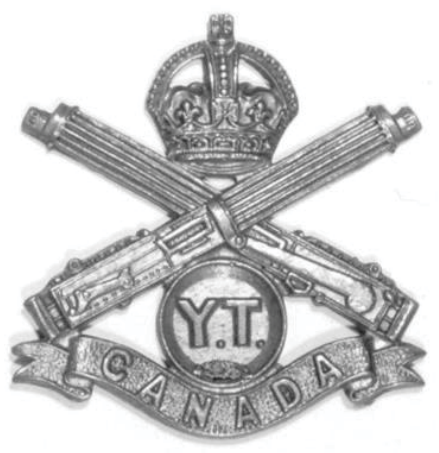

Fig. 38. Was this gilt YMMGB collar badge a gift to Martha Black in Christmas 1917? www.marway-militaria.com 
During my years of collecting I was very fortunate to acquire an entire set of badges and medals awarded to one soldier. Harold Oldham was born in England in June 1892 and immigrated to Canada in 1910 to work on a farm near Rosthern, Saskatchewan. Oldham felt the urge to see the vast West and "kicked around" for some time at various jobs; at one time he was employed with the Grand Trunk Railroad.

In the summer of 1914, he and a friend travelled by canoe down the Athabasca River through Alberta, and then down the Mackenzie River in the Northwest Territories. Upon finally reaching the Arctic Ocean, the pair travelled along the Yukon River through northern Yukon Territory to Fort Yukon, Alaska. There they boarded a steamship and headed up river to Dawson City where they arrived in September.

Almost immediately Oldham enlisted with the Royal Northwest Mounted Police and served his entire career in Dawson. During this service he participated in a gruelling sled dog run from Dawson City to Fort McPherson and Arctic Red River, in the Northwest Territories. The entire distance was over 1,000 miles and during some the most severe weather ever recorded with temperatures reaching -70 F.

With the outbreak of the First World War, many RWNMP members wanted to enlist with the CEF. They were initially denied as their services were needed on the home front. One member even took to deserting in order to enlist. Eventually, Mounted Police were allowed to enlist and, with about thirty other RNWMP members, Oldham enlisted in September 1916 with the Yukon Infantry Company with the rank of Sergeant (Fig. 39).

Oldham served thoughout the rest of the war and, with the other Yukoners, saw service in France with the $2^{\text {nd }} C M M G B$. After the war, Oldham rotated back to Canada in May 1919. He settled in British Columbia and was employed with the BC Forest Service. $\mathrm{He}$ did a wide variety of jobs including horse wrangler, fire fighter, sur- Fig. 39. Cst Harold Oldham RNWMP, left; Sgt. Oldham, veyor, woodsman, and right. Author's collection 
park ranger. When hostilities again broke out in 1939, Oldham enlisted with the Canadian Army (Figs. 40 \& 41).

Oldham entered as a lieutenant with the Royal Canadian Engineers and served the entire war in BC. By war's end he had risen to the rank of Major. For a brief time in 1946 he served in Whitehorse with the Northwest Highway System of the Alaska Highway.

Upon his release from the military, Oldham was employed with the $\mathrm{BC}$ government as a civil engineer and one of his accomplishments was his work on the ferry ports at Vancouver and Victoria. Oldham died in September 1987.
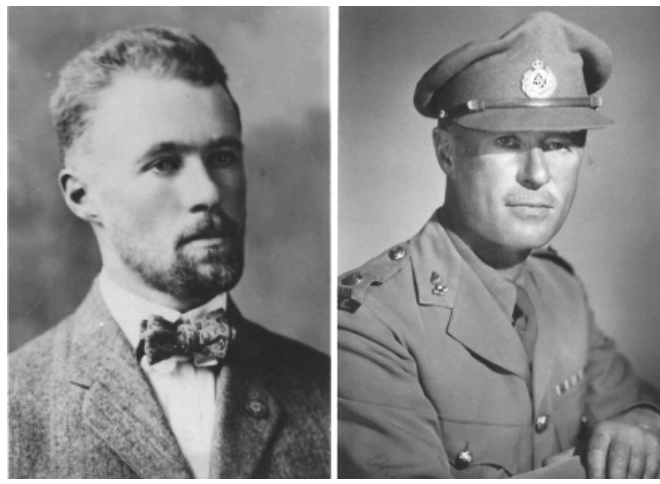

Fig. 40. Forest Ranger $\mathrm{H}$. Oldham 1920s in civilian attire, left. Major H. Oldham, RCE, right. Author's collection

Fig. 41. Pte. H. Oldham service medals and pins. From left the medals are: British War Medal, Victory Medal, Canadian Volunteer Service Medal, and 1939/45 War Medal. The pins at bottom from left are $1^{\text {st }} W W$ For Service At The Front, Canadian Machine Gun Corps Association, Royal Canadian Legion, $2^{\text {nd }}$ WW General Service, Royal Canadian Engineers. Author's collection

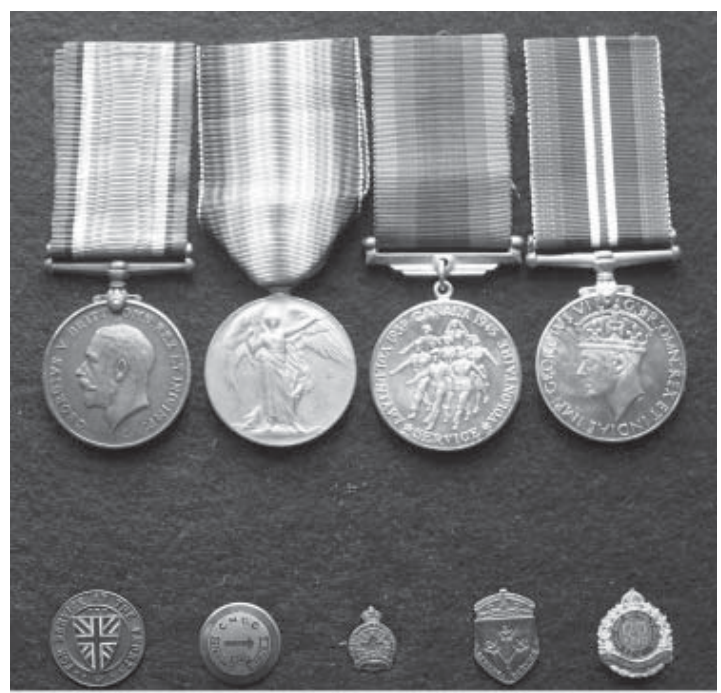


Not all collecting treasures come in the form of badges or medals. I was very fortunate to copy numerous photographs from an album that was once owned by Oldham. In this album several other RNWMP members who had enlisted with the Yukon Infantry Company are identified. One such member was Thomas Greenaway who, like Oldham, immigrated to Canada. Greenaway served with the Coldstream Guards from 1908 to 1913 after which he took his release and immigrated to Canada. In the same year, he enlisted with the RNWMP and after training in Regina, Saskatchewan was posted to Dawson City, serving until 1916. He too enlisted with the Yukon Infantry Company being promoted to the rank of sergeant. Several years ago I acquired an Elgin gold pocket watch with Greenaway's name engraved on it (Figs. 42 \& 43). The badges of the units he once proudly served with - the Coldstream Guards, RNWMP, and the YMMGB - were engraved on the watch covers. This truly showed that Greenaway's time in service meant a lot to him.

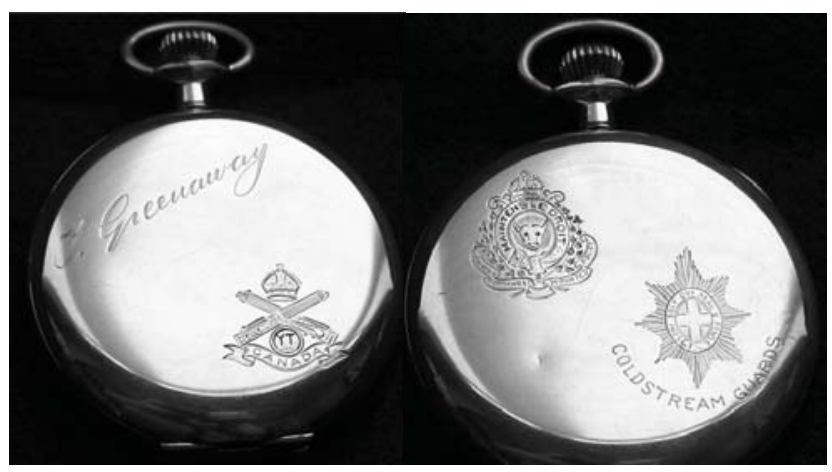

Figure 42. The front cover, left, and rear cover, right, of Sgt. T. Greenaway's pocket Elgin watch engraved with the badges of the YMMGB, left, and the RNWMP and Coldstream Guards, right. Author's collection

Fig. 43. Sgt. T. Greenaway in Surrey, England, 1917. The badges worn are general issue machine gun corps style. Author's collection

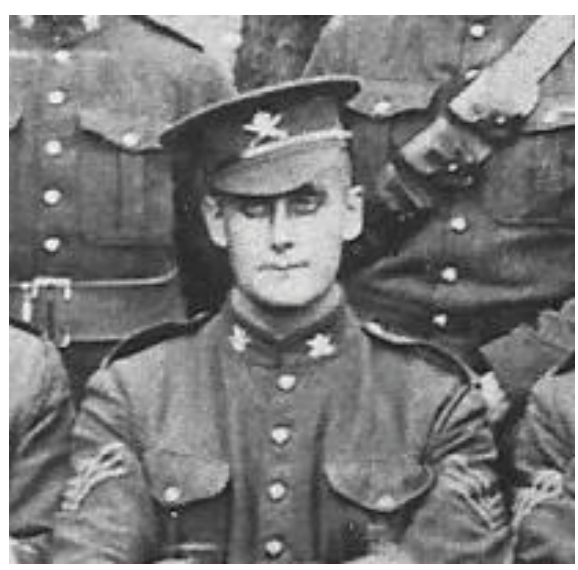




\section{Medals Awarded to Yukon CEF Units}

The second part of my paper will cover the medals awarded to the men who served in these Yukon units. Not all soldiers mentioned here were original Yukoners. The following citation details are based on quoted citations from the London Gazette as well as my research of the military file associated with the individuals and units. There is a vast interest in collecting military medals, showing the importance of how these items define the soldier who received the awards.

\section{Distinguished Service Order, DSO}

Commissioned officers appointed to the Order must first have been honourably Mentioned in Dispatches. The DSO was awarded for "Meritorious of Distinguished service in the field, or before the enemy." After 1 January 1917 it was awarded for gallantry in the face of the enemy not just for distinguished service. For subsequent acts of distinguished service or gallantry, a gold bar with the Imperial Crown in the

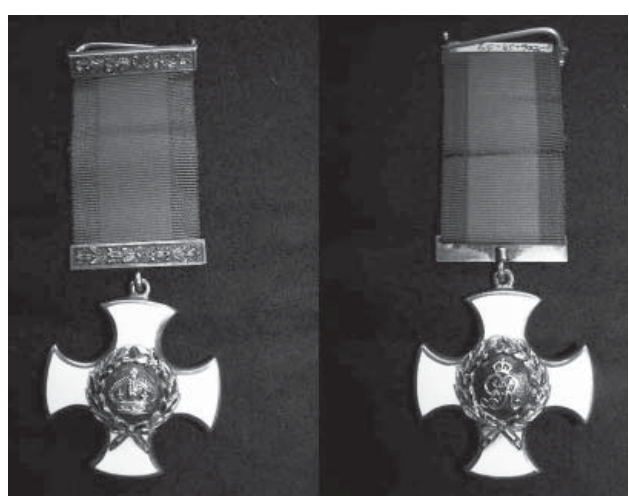

Fig. 44. The Insignia of the British Distinguished Service Order, obverse left and reverse right. Author's collection centre would be added to the ribbon (Fig. 44)

Meurling MC, Harry Frederick Victor, Maj. (A/ Lt. Col.) 2nd Canadian Motor Machine Gun Brigade, London Gazette 01/01/19, Canada Gazette 02/08/19, P2464 - New Year award 1919. No citation (Fig. 45).

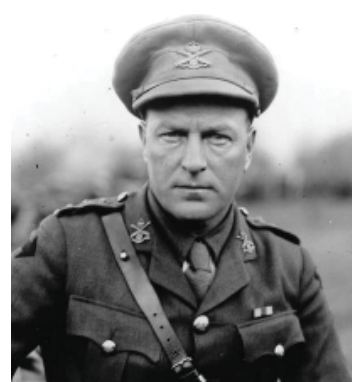

Fig. 45. Capt. H. Meurling, MC. National Archives of Canada \#PA 2535 


\section{Military Cross, MC}

This medal (Fig. 46) may be awarded to captains, subalterns, and warrant officers "for distinguished conduct and meritorious service in battle." In 1920 it was published that the award was for gallant and distinguished services in action. A silver bar with an imperial crown centred would be added to the ribbon for additional acts of gallantry.

Fig. 46. The Military Cross, obverse. www. northeastmedals.co.uk

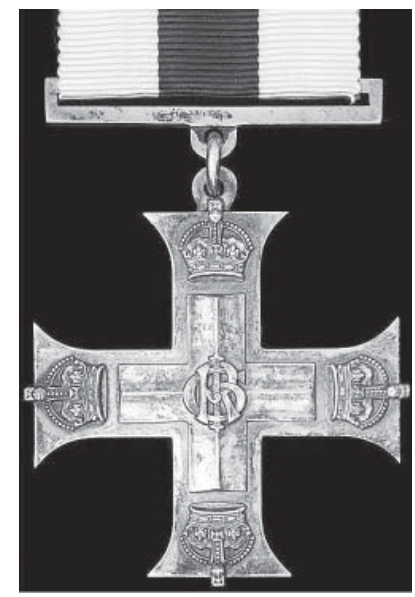

Babb, Richard, Lt. Canadian Machine Gun Corps, LG 04/25/18, CG 06/01/18, P4198-For conspicuous gallantry and devotion to duty. When all the officers of two machine gun batteries except himself had become casualties he took charge of the sixteen guns and kept them working and the men steady under very heavy shelling (Fig. 47).

Black, Lyman Munger, Lt. Canadian Machine Gun Corps, LG 07/26/18, CG 08/31/18, P847-For conspicuous gallantry and devotion to duty. When the enemy was rapidly advancing, he handled his motor machine guns with great daring, time after time checking the enemy's advance and giving the tired infantry time to reorganize. On another occasion he rushed his machine guns up to hostile cavalry, causing them enormous casualties (Fig. 48).

Black, William, T/Lt., Canadian Machine Gun Corps, LG 08/16/17, CG 10/13/17, P1163-For conspicuous gallantry and devotion to duty. During an attack upon an enemy position he gave invaluable assistance to the infantry, working in an exposed position and directing his machine gun fire upon enemy reinforcements. Though under heavy fire he personally worked his guns and attended to the wounded, setting a fine example of courage and energy throughout (Fig. 49).
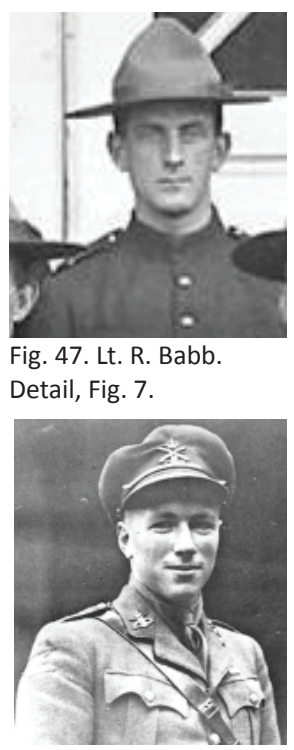

Fig. 48. Lt. L. M. Black. NAC \#PA 6951

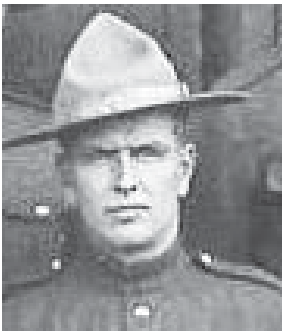

Fig. 49. T/Lt. W. Black. Detail, Fig. 7. 
Edelstan, Jerome, Lt. (A/Capt), Royal Garrison Artillery (Territorials) (former Boyle's Yukon Machine Gun Detachment), LG 03/06/18, P6505 no citation (Fig. 50).

Meurling, Harry Frederick Victor, Capt., Yukon Motor Machine Gun Battery, LG 10/01/17, CG 10/02/17, P2792 - For conspicuous gallantry and devotion to duty. He commanded a group of machine guns with great courage and skill throughout the action, materially assisting in the success of operations.

Ryley, Charles John Sheffield, Lt., 4th Battalion Canadian Machine Gun Corps (former Boyle's Yukon Machine Gun Detachment) LG 30/07/19, CG 20/09/19, P20 Supplement - During the operations against Bourlon Wood on September 27, 1918, he led his men with great courage and coolness through to the final objective. He got his guns into action against large parties of the enemy on the flanks, and killed the horses of a battery of field artillery, Fig. 51. Lt. C. Ryley. Detail which resulted in their capture by our troops. from Boyle's MGD, Fig. 7. During this period his guns were under heavy fire, and his battery suffered severe casualties, but his good judgment and courage were a splendid example to his men (Fig. 51).

\section{Distinguished Conduct Medal, DCM}

This medal was awarded to warrant officers, non-commissioned officers, and enlisted men for distinguished conduct and outstanding acts of gallantry in the field of battle. It was the second highest award for gallantry in the field of action, after the Victoria Cross, for army ranks below commissioned officers. A silver laurelled bar was added for subsequent acts of distinguished conduct (Fig. 52).

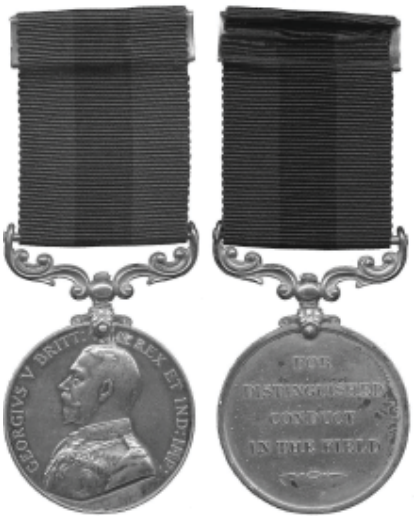

Fig. 52. The Distinguished Conduct Medal, obverse left and reverse right. www.liveauctioneers.com 
Blaikie, Anthony, Sgt. MM, 107121, Canadian Machine Gun Corps, LG 28/03/18, CG 11/05/18, P3917 - For conspicuous gallantry and devotion to duty when in command of four machine guns, his officer and other NCO's being casualties. Under very heavy shelling in the open he repaired slightly damaged guns and kept them in action, and helped and dressed wounded (Fig. 53).

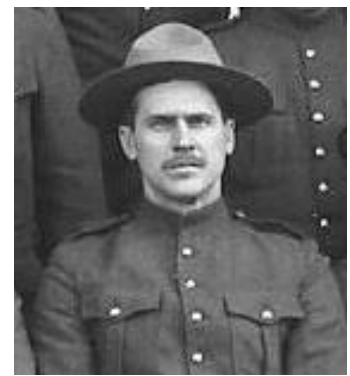

Forrest, Anthony Edward, Battery Sgt Major, Fig. 53. Sgt A. Blaikie. 107232, Canadian Machine Gun Corps, LG Detail, Fig. 7. 03/09/18, CG 19/10/18, P1441A - For conspicuous gallantry and devotion to duty. After his officer had been killed he took command of the motor machine guns and in severe fighting checked the enemy's advance. He engaged hostile cavalry at close range and when covering the withdrawal of the infantry and almost surrounded, fought his way out, with the loss of only two guns, after causing enormous casualties. Amended CG May 10, 1918, P18 Supplementary (Fig. 54).

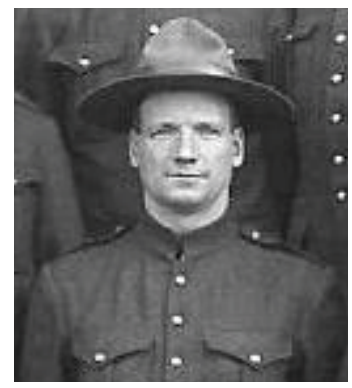

Fig. 54. BSM A. Forrest. Detail Fig. 7.

\section{Military Medal, MM}

The MM was awarded to warrant officers, non-commissioned officers, and enlisted men for individual or associated acts of bravery in the field of battle on the recommendation of a commander-in-chief in the field. A silver laurelled bar was added for subsequent acts of bravery (Fig. 55).

Belney, Louis Eugene, Pte., 2004505 (former Yukon Infantry Company) LG 03/07/19-No citation.

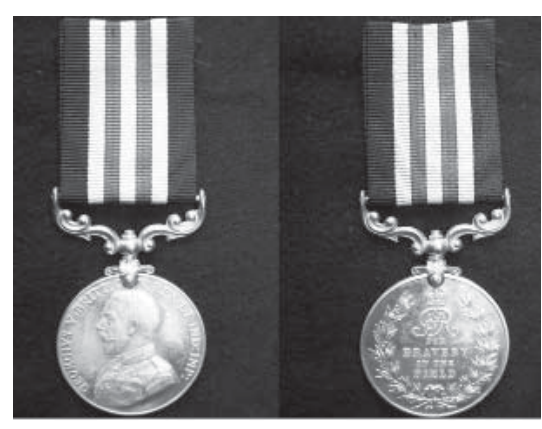

Fig. 55. The Military Medal, obverse left and reverse right. This medal was awarded to Cpl. G.E. Marshall. Author's collection

Blaikie, Anthony, Sgt., 107121

Canadian Machine Gun Service, LG 22/01/17-For conspicuous good work and devotion to duty near Courcelette from the 13th to the 19th November, 1916 when the machine gun group under the O.C. of the Yukon Motor Machine Gun Battery were in action practically day and 
night. During the action of November 18th 1916, his belt filling machine was destroyed, he at once organized belt filling by hand and through his cool and efficient manner under heavy shell fire he succeeded in keeping his men working to the utmost and supplying badly needed ammunition.

Currie, William Kenneth, Pte., 107169, Canadian Machine Gun Corps, LG 19/11/17-On August 9th 1917, during a raid on the enemy's trenches, when two guns were destroyed by shell fire, he doubled the rate of fire of his gun and kept it in action although compelled to make extensive repairs under very heavy shell fire, which necessitated his greatly exposing himself. At all times he showed the greatest contempt for his own personal safety (Fig. 56).

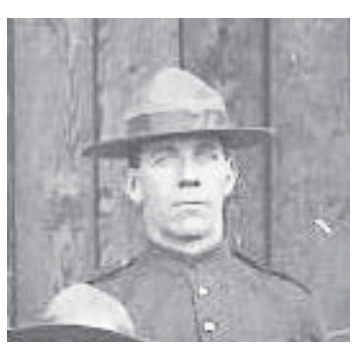

Fig. 56. Pte. W. Currie. Detail, Fig. 7.

Doherty, Thomas, Pte., 107191, 2nd Canadian Motor Machine Gun Brigade, LG 11/12/18-No citation

Lawless, Herbert Maxwell, Pte., 107379, Canadian Machine Gun Service, LG 26/04/17-For conspicuous gallantry during a raid on the enemy's trenches near Souchez on February 22, 1917. An enemy trench mortar shell landed amongst the crew of his gun, killing one, wounding three and burying himself and his Officer. He rendered most valuable assistance after recovering from the shock, by helping in moving guns, material and wounded.

Marshall, George Eric, Cpl., 2004567, 2nd Canadian Motor Machine Gun Brigade, LG 13/03/19 - No citation (Fig. 57).

McAlpine, Frank, Sgt., 107398, Canadian Motor Machine Gun Service, LG 22/01/17 - For conspicuous good work and devotion to duty near Courcelette from the 13th to the 19th November, 1916 when the machine gun group under the O.C. Yukon Motor Machine Gun Battery were in action practically day and night. On the 18th November, he was knocked down by a shell and badly shaken but continued to look after his guns

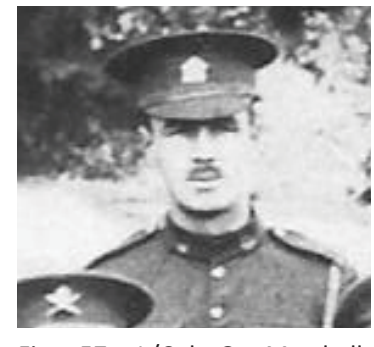

Fig. 57. L/Cpl G. Marshall. Author's collection

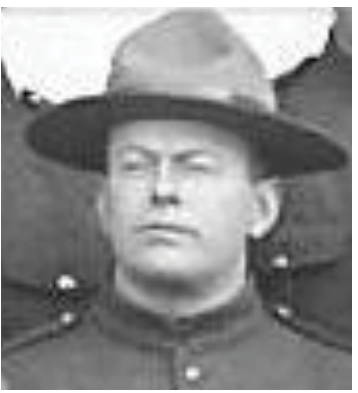

Fig. 58. Sgt. F. McAlpine. Detail from Boyle's MGD, Detail, Fig. 7. ammunition supply in a most efficient manner (Fig. 58). 
Milatovich (misspelled Milstovich on medals card), Marko, Pte., 1015585, P.P.C.L.I., (former Yukon Infantry Company) LG 11/02/18 - No citation

Penhall, Sidney, Pte., 874631, Canadian Motor Machine Gun Battery, LG 13/09/18 - No citation.

Peppard, Ernest Laurence, Pte., 107498, Canadian Motor Machine Gun Service, LG 22/01/17 - For conspicuous good work and devotion to duty near Courcelette from the 13th to the 19th November, 1916 when the machine gun group under the O.C. Yukon Motor Machine Gun Battery were in action practically day and night. On numerous occasions and especially during the action of November 18th he kept his gun working in a most efficient manner under very heavy shell fire and very trying circumstances (Fig. 59).

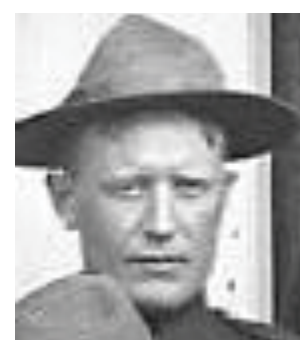

Fig. 59. Pte. E. Peppard. Detail, Fig. 7.

Small, Robert Arthur., Cpl., 107572, Canadian Machine Gun Corps, LG 19/11/17 - On 9th Aug 1917 during a raid on enemy's trenches was in charge of 2 machine guns. Three of his gun numbers became casualties, he organized his gun crews with himself acting as No 1, rectifying stoppages under heavy shell fire, regardless of his own safety, thus enabling fire to be maintained until the completion of the operation (Fig. 60).

Stewart, Thomas F., Sgt., 132224, Canadian Motor Detail, Fig 7.

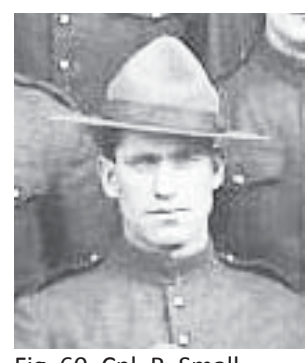

Fig. 60. Cpl. R. Small.

Machine Gun Service, LG 22/01/17 - For conspicuous good work and devotion to duty near Courcelette from the 13th to the 19th November, 1916 when the machine gun group under the O.C. Yukon Motor Machine Gun Battery were in action practically day and night. On the 18th November 1916 under intense bombardment he supervised his guns and ammunition supply in a most efficient manner although on several occasions his belt filling place was blown in.

Walker, Harry George, Pte., 107649, Canadian Motor Machine Gun Service, LG 22/01/17 - For conspicuous good work and devotion to duty near Courcelette from the 13th to the 19th November, 1916, when the machine gun group under the O.C. Yukon Motor Machine Gun Battery were in action practically day and night. On the 18th November, a shell blew in his machine gun emplacement, he repaired same, and continued firing, when another shell tore off the right handle and side roller, he made temporary repair and continued firing. 


\section{Meritorious Service Medal, MSM}

The MSM was awarded to all enlisted ranks for "good, faithful, valuable and meritorious service, with conduct judged to be irreproachable throughout." In 1916 the medal was also awarded for acts of gallantry. A silver laurelled bar was added for subsequent acts of gallantry (Fig. 61).

Aldcroft, William, Armourer, Sgt, 107067 Canadian Machine Gun Corps, 1st Canadian Motor Machine Gun Brigade, LG 18/01/19, CG 12/04/19

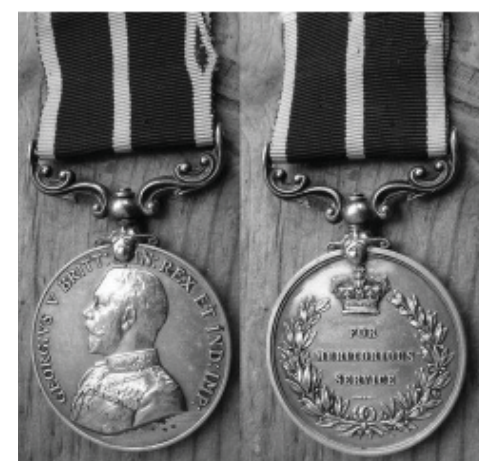

Fig. 61. The Meritorious Service Medal, obverse right and reverse left. www.medalsearch.co.uk

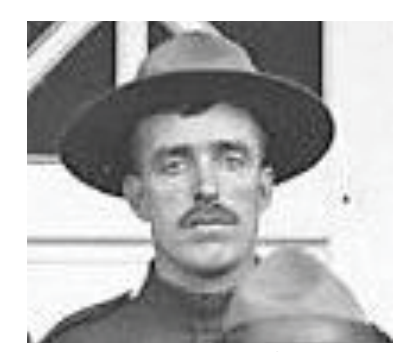

Fig. 62. Sgt. W. Aldcroft. Detail, Fig. 7.

\section{Mention in Despatches, MID}

The MID, a bronze oak leaf, was awarded to all ranks to bring forward, to higher authorities, names deserving notice for their actions or service in the field. The recipient's name was published in the London Gazette to make it official. There was also a certificate issued to the recipient. The dimensions of the insignia of the MID is $3.60 \mathrm{~cm} \times 0.87 \mathrm{~cm}$ and worn on the Victory Medal ribbon at an angle of 60 degrees. If no Victory Medal was awarded, then the insignia was worn on the War Medal. There is no citation for MIDs and a description for the award might possibly be given in a unit's war diary (Fig. 63).

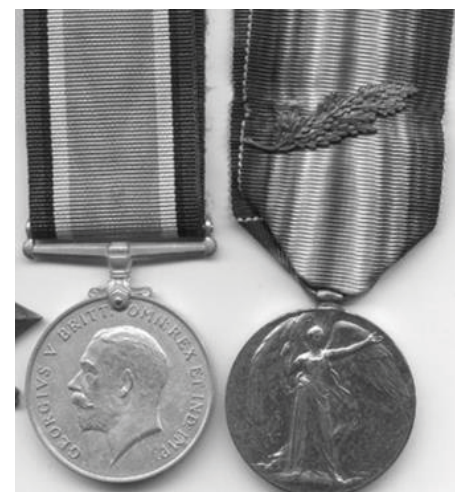

Fig. 63. A typical First World War trio, 1914/15 Star, War Medal and Victory Medal. The insignia of the Mention in Despatches on the Victory Medal, right. www.camc. wordpress.com 
Aldcroft, William, Sgt Major, 107067, Canadian Machine Gun Corps, LG 28/12/17, No.30488

Edelstan, Jerome, Lt. (A/Capt), MC, Royal Garrison Artillery (Territorials) (former Boyle's Yukon Machine Gun Detachment), LG 05/06/19, P7219

Meurling, Harry Frederick Victor, Lt. Col., MC, 2nd Canadian Motor Machine Gun Brigade, LG 27/12/18, No. 31089

Ryley, Charles John Sheffield, Lt., MC, Canadian Machine Gun Corps, LG 27/12/18, No. 31089

\section{Foreign Awards: Croix de Guerre (French)}

Created in 1915, the Croix de Guerre (Fig. 64) was awarded either to an individual or to a unit, to those soldiers who distinguished themselves by acts of heroism involving combat with the enemy. This award is similar to the British Mention in Dispatches. The Croix de Guerre are always awarded with an attachment. The lowest degree is represented by a bronze star and the highest degree is represented by a silver palm-bronze star for those who were mentioned at the regiment or brigade level; silver star for those mentioned at the division level; silver gilt star for those who were mentioned at the corps level; bronze palm for those mentioned at the army level. Silver palm represents five bronze mentions.

Meurling DSO, MC, Harry Frederick Victor, Lt. Col., 2nd Canadian Motor Machine Gun Brigade, LG 07/01/19, CG 29/03/19

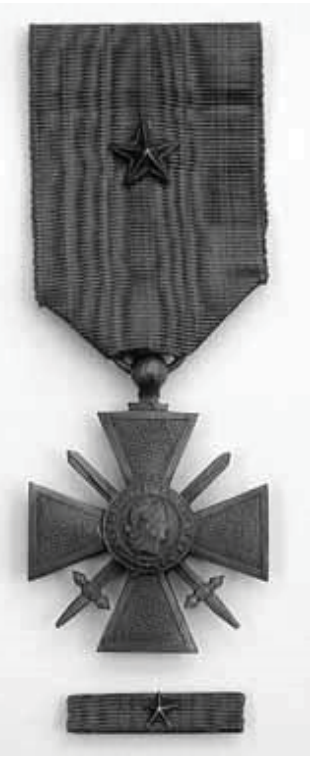

Fig. 64. Croix de Guerre with bronze star and uniform undress ribbon bar below.

www.masshist.org 
Foreign Awards: Order of the White Eagle with Swords $5^{\text {th }}$ Class (Serbia)

The Order of the White Eagle (Fig. 65) was created in 1883 and was awarded to Serbian and Yugoslav citizens for achievement at times of peace or war. Introduced in 1915, this order had a War Merit Division where the insignia had crossed swords between the Royal Crown and eagle's heads. It was conferred for conspicuous bravery of officers in the field.

Edelstan MC, Jerome, Lt. (A/Capt), Royal Garrison Artillery (Territorials) (former Boyle's Yukon Machine Gun Detachment), LG 26/02/20

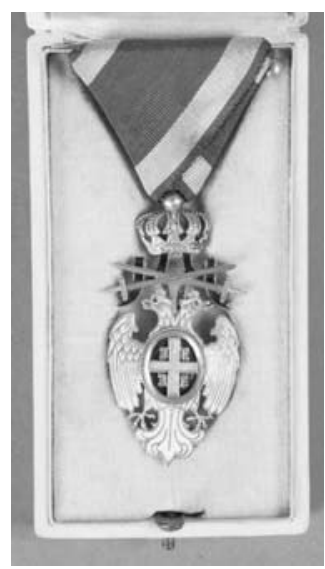

Fig. 65. A cased Order of the White Eagle with Swords 5th Class.

www.us.expertissim.com

\section{Awards to Honorary Lt. Col. Joe Whiteside Boyle, DSO}

"The King of the Klondike," as Joseph Whiteside Boyle was commonly known, was many things, but most of all he was a mining entrepreneur during the Klondike Gold Rush of 1898. There have been no fewer than four publications written about his life history, but I will focus solely on his military awards, which were a bit of an oddity.

When Boyle was in the Yukon running his gold operations, the First World War broke out and Boyle immediately did whatever he could to support the war effort. Boyle was made an honorary lieutenant colonel in the Canadian Militia because of his generous donation of a fifty man machine gun unit that he fully equipped and paid for out of his own pocket. Boyle was too old to command the unit and therefore the name changed to the Yukon Motor Machine Gun Battery.

It was probably poor judgment on the part of the Canadian Military headquarters that they decided Boyle was not capable of doing more, and therefore "set him aside," as it were. Not wanting to sit out the war while the former commissioner of the Yukon, George Black, received a commission and a unit to command, Boyle set out to seek some job from the circle of friends he made while in London, England. With the right connections, in 1917 he was assigned to the American mission heading to Russia to sort out the railway system that had been in a mess since the war started. 
From there, things led to an array of adventures for Boyle that no Hollywood producer could dream up. Having virtually no military experience whatsoever, and holding the rank of honorary lieutenant colonel, Joe Boyle was a rare breed of leader. He knew how to organize and motivate people, and did what it took to get a job done. When he succeeded, it was through his strong character and unshakeable courage, combined with foresight and daring. It amazes me that no one has produced a movie or a TV documentary on Boyle. During all his adventures Boyle even had time to have an alleged love affair with the Queen of Romania.

In a span of two years, while serving with the military commission in Russia and Romania, Joe Boyle was recognized no less than nine times by four different nations (Fig. 66). One of the awards was a Distinguished Service Order from Great Britain. Yet despite all the honours and awards bestowed upon Boyle, and because he was an honorary lieutenant colonel in the Canadian Militia, he did not qualify for a general service pair of medals for service during the First World War.

The Russian awards for Boyle were not gazetted like the other awards but were mentioned in a special War Office List communication with other named officers and soldiers dated 16 July 1921. This letter indicated the Russian awards for Boyle at a lower level. This more than likely upset Boyle, especially since his own country snubbed him from any award.

On 29 October 1921, Boyle wrote to the Canadian Adjutant General indicating that his Order of St. Vladimir 4th Class and Order of St. Stanislas 2nd Class (Fig. 67) were made "with swords" and the Order of St. Anne (Fig. 68) was "on the sword," which was stated incorrectly in the July 16 letter. Who is wrong, Canadian Military Headquarters or Joe Boyle, the actual person receiving the award? Boyle, in his response

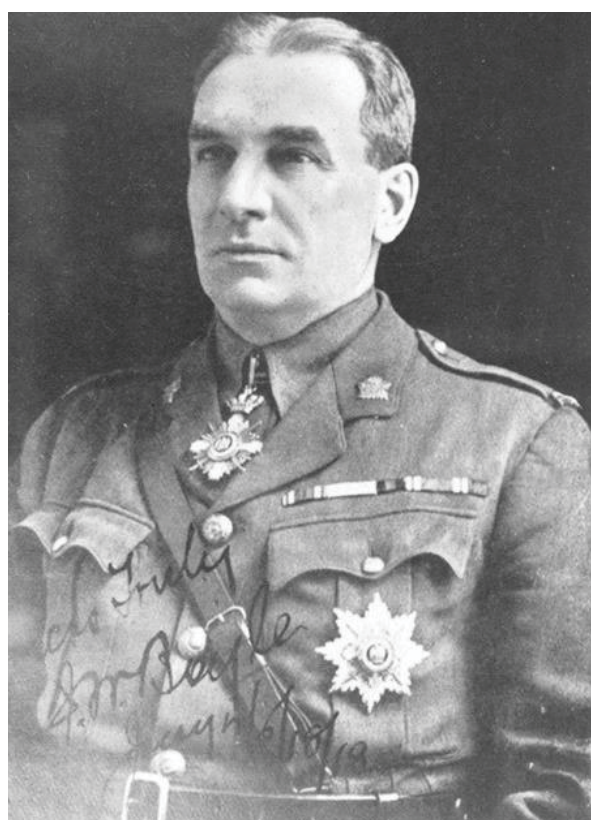

Fig. 66. Honorary Lt. Col. Joseph Whiteside Boyle, DSO, wearing the Order of the Star of Romania, Grand Cross, neck medal and breast star. The collar badges and shoulder titles are Boyle's Yukon MGD. Photo: Max Fraser Video Productions 
letter, continued to state that his awards were made by the Russian Imperial Forces in the field and not by the Kernesky government. The following medals are examples of what Boyle would have been awarded and are not the actual awards. They are shown in the sequence they were presented.

Order of St. Stanislas, 2nd Class with swords (Russia), War Office List, 16 July 1921; for presence of mind, courage and leadership, by coordinating defences this allowed the main body of the Russian army to withdraw and prevented an enemy rout at Tarnapol, Russia, Summer 1917. Presented by General Lavr G. Kornilov.

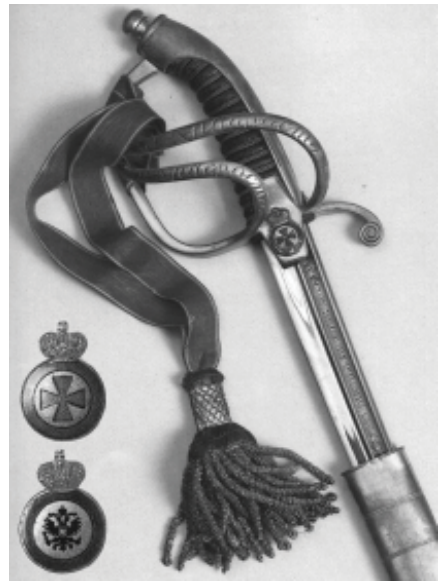

Fig. 68. The Order of St. Anne, 4th Class on the sword. The insignia is attached to a sword hilt with additional ribbon and sword knot. In the left corner of the photo is the insignia for Christian, top, and nonChristian, bottom, recipients. www. commons.wikimedia.org

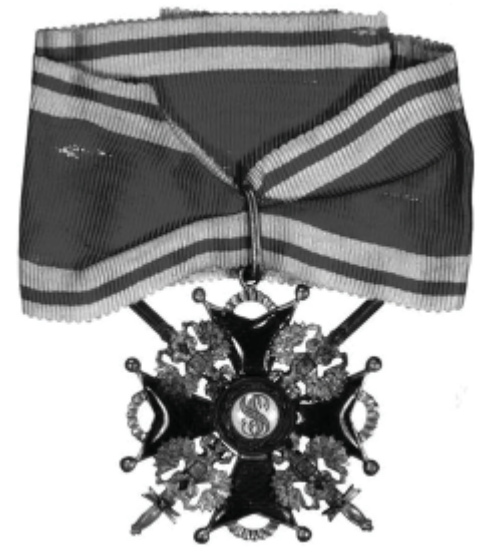

Fig. 67. The neck insignia of the Order of St. Stanislas 2nd Class with swords. www.mannerheim.weebly.com

Order of St. Anne, 4th Class on the sword (Russia) War Office List, 16 July 1921; for valour in the field during the incident at Tarnapol, Summer 1917. Presented by General N.N. Dukhonin. 
Order of St. Vladimir, 4th Class with swords (Russia), War Office List, 16 July, 1921; for tremendous efforts to reestablish the transportation systems (railways) on the Romanian front, Autumn 1917. Presented by General D.G. Shcherbachev.

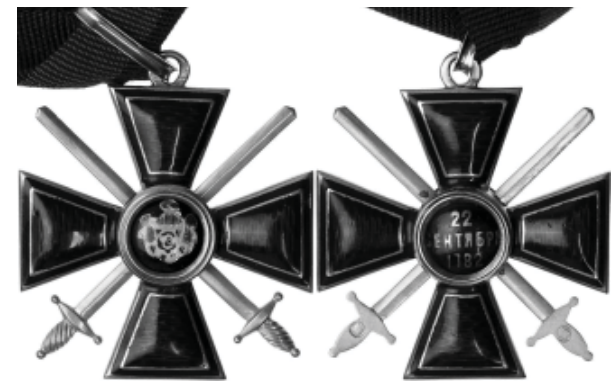

Fig. 69. The obverse left and reverse right of the Order of St. Vladimir 4th Class with swords. www.goldbergauctions.com

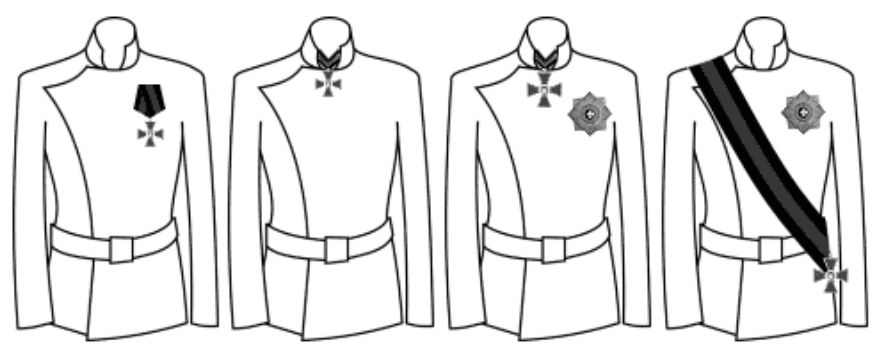

Fig. 70. The classes of the Order of St. Vladimir. From right: $1^{\text {st }}$ class, $2^{\text {nd }}$ class, $3^{\text {rd }}$ class, and $4^{\text {th }}$ class. Boyle would have worn his medal above his uniform left breast pocket flap. www.wikipedia.org

Order of the Crown of Romania, Commander, L.G. 24/10/1919 No.31615; for the return of the Foreign Ministry's Archives and Crown Jewels from Moscow, December 1917. Presented by King Ferdinand of Romania.

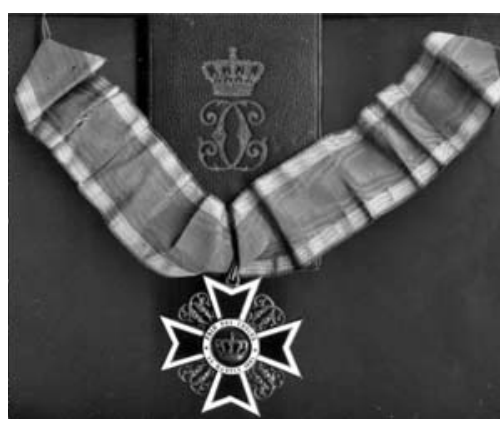

Fig. 71. The Order of the Crown of Romania, Commander with transmittal box. This medal would be worn at the neck. www.delcampe.net 
Order of the Star of Romania, Grand Cross, L.G. 24/10/1919 No.31615; for rescue of Romanian hostages from the Bolsheviks in March 1918. Presented by King Ferdinand of Romania.

Fig. 72. Order of the Star of Romania, Grand Cross, obverse and reverse neck medal and breast star. www.ordersandmedals.net

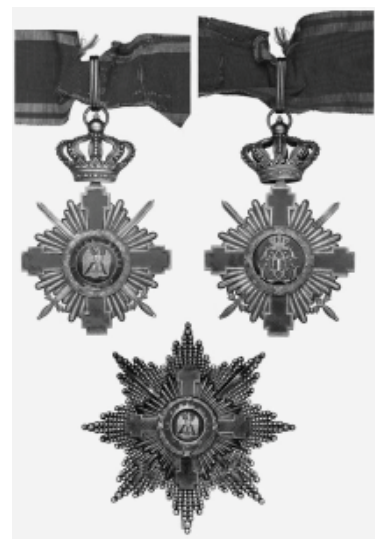

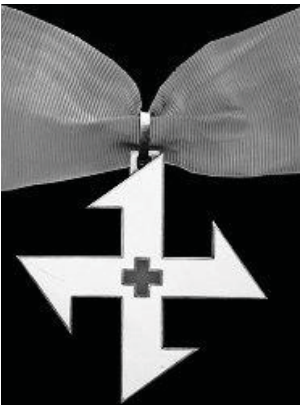

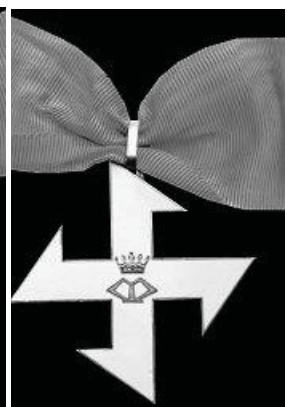

Fig. 73. The Romanian Order of Queen Maria Cross, $1^{\text {st }}$ Class worn at the neck. Obverse left and reverse right. Queen Marie's sigil is on the reverse. www.medals.org.uk
Order of Queen Maria Cross, First Class (Romania), L.G. 24/10/ No.31615; for the prevention of the loss of Russian Red Cross stores and other essential equipment to the Central Powers and the use of these stores to be used by the people of Romania and the army, Fall 1918. Presented by Queen Maria of Romania.

Croix de Guerre (French) L.G. 24/10/1919 No.31615; "A collabore etroitement avec l'Armee Francaise, et lui a rendu de precieux services par les missions qu'il a accomplies en Bessarabie et en Ukraine" (Collaborated closely with the French Army and rendered precious service by the missions he accomplished in Bessarabia and the Ukraine), November 1918. Presented by French General H.M. Berthelot.

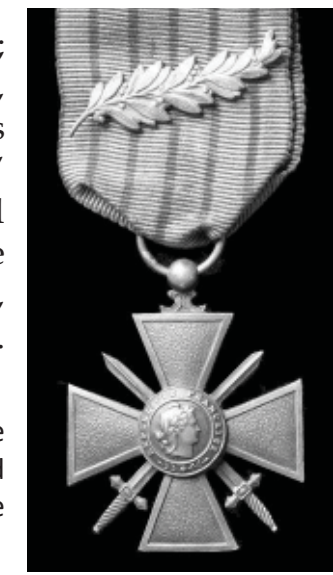

Fig. 74. French Croix de Guerre avec bronze palme, obverse. The citation of this award for Boyle was at the army level and hence the addition palm leaf. www.pinterest.com 
Distinguished Service Order, LG 03/06/19, CG 05/07/19, P2 Supplementary-Awarded on the occasion of His Majesty's Birthday 1919. No citation. Amended Canada Gazette September 4, 1920, Page 853. Awarded for distinguished services rendered in connection with military operations in Eastern Russia.

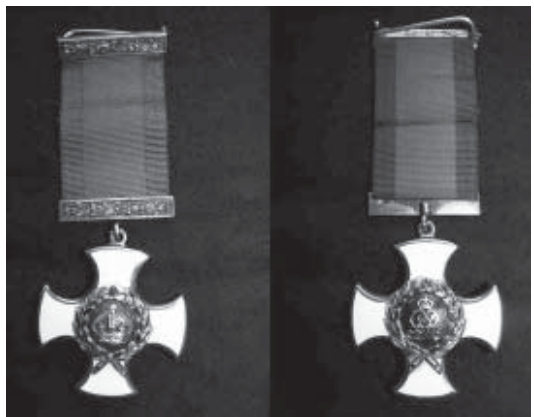

Fig. 75. The Insignia of the British Distinguished Service Order, obverse left and reverse right. Author's collection

Brought to the Notice of the Secretary of State for War for Valuable Services Rendered in Connection with Military Operations in the Field, M.I.D. 'A' List - Boyle, Joseph Whiteside, Honorary Lieutenant Colonel, Canadian Militia, LG 12/01/20, No. 31728

Those individuals who had their "names brought to notice" ('A' List) were listed in the London Gazette. This award was generally for services on the home front and not in the face of the enemy. It could also be awarded for prisoners of war. This award was equivalent in all respects to the Mention in Dispatches and a bronze oak leaf insignia was issued (Fig. 76). As with the MiD, there is no citation for "names brought to notice."

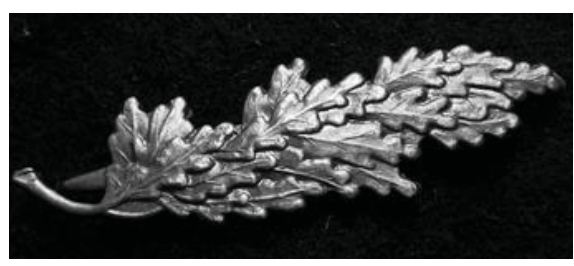

Fig. 76. The bronze oak leaf insignia of the Mention in Despatches. If awarded without military service medals, then the insignia would be worn above the flap of the left breast pocket on the uniform. A certificate would also be issued with this award. Author's collection 
Any member of the military, Canadian or British, who served during the First World War, was eligible for a standard group of medals for general service. This would be the 1914-15 Star, the 1914-1918 War Medal, and the Victory Medal. Boyle would have qualified for the War and Victory medals but was not awarded them as he was not fully recognized by the Canadian Military Headquarters as being in the Canadian Expeditionary Forces. This is truly shameful of a nation that might have felt a little embarrassed by all that Boyle had accomplished. But like anything else, all good things do come to an end.

The strain of his adventures took its toll on Boyle. Once having a stroke, being of ill health with other complications and requiring a nurse to assist him, Boyle went to England, the home of Teddy Bredenberg, an old friend from his Klondike days. Upon Boyle's death on 14 April 1923, Boyle was interned at Hampton Hill, Middlesex, England. Queen Marie of Romania had sent and ordered the placing of an ancient Romanian stone cross along with a stone urn at the head of a granite slab covering the grave of this famous Canadian (Fig. 77).

The granite slab (Fig. 78) is inscribed with "Lt. Col. Joseph Whiteside Boyle, C.B.E., DSO." The CBE or the Commander of the Order of the British Empire, was a very high honour within the British award system (Fig. 79). A check of research material and biographies indicate that Boyle was never awarded the CBE. In Leonard Taylor's book The Sourdough and The Queen, Boyle's daughter, Flora, knew the reason why the CBE was engraved on his tombstone but would not divulge it. The secret was entrusted to her by Queen Marie of Romania and it went with Flora to her grave.

The cross above Boyle's name is actually the image of the Order of Queen Maria Cross. This medal was personally presented to Boyle by Queen Marie in 1918. Upon further inspection of the photos of Boyle's grave one can make out an engraving of a sigil or emblem below his epitaph in the right hand corner (Fig. 80). This was Queen Marie's personal monogram. Was this a way of showing the Queen's enduring love for Joe Boyle? We may never know. A veiled lady, dressed in black, was seen visiting Boyle's grave on the anniversary of his death every year. There she would plant fresh orange lilies in the urn and tend to the weeds. When Queen Marie died before the start of the Second World War, the lady in black stopped coming to Boyle's grave.

What happened to Boyle's uniforms, medals, and other possessions? After his death, Joe's son, Joe Jr., came to the residence of Teddy Bredenberg and loaded all of Boyle's possessions into a couple of moving vans. Flora Boyle did manage to see some of the items once in 1926, but since then 


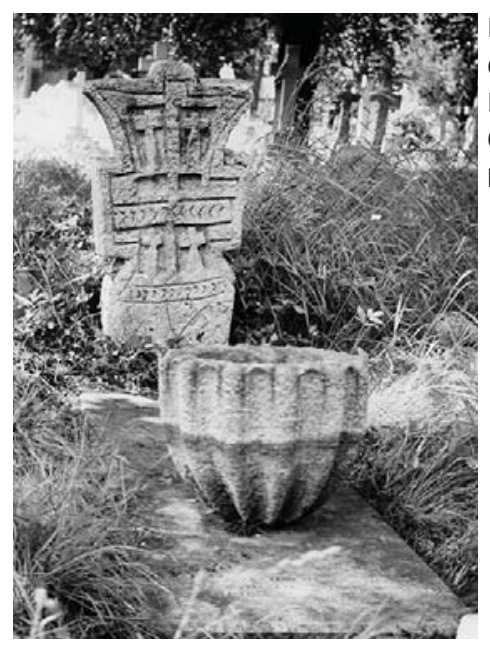

Fig. 77. Lt. Col. Joe Boyle' grave as it was discovered in England by the late Maj. Len Taylor, i/c Canadian Military Sensor, Canadian Army in 1945. www.woodstock. library.on.ca

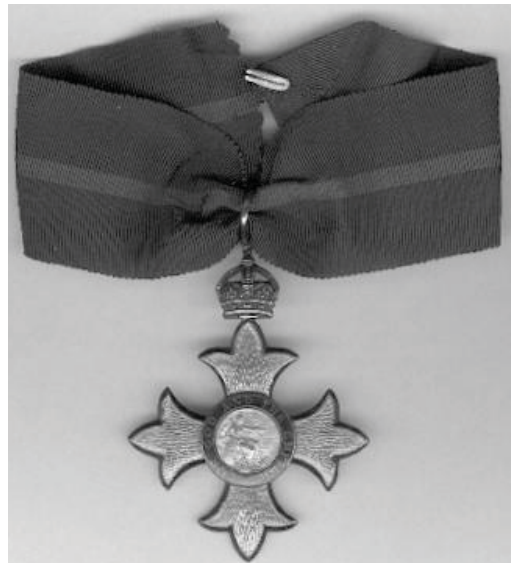

Fig. 79. The Most Excellent Order of the British Empire, Commander (C.B.E.), Military, 1st type, 1917-1935 issue. Although mentioned on his grave, Boyle never received this honour, or did he ? www.medal-medaille.com

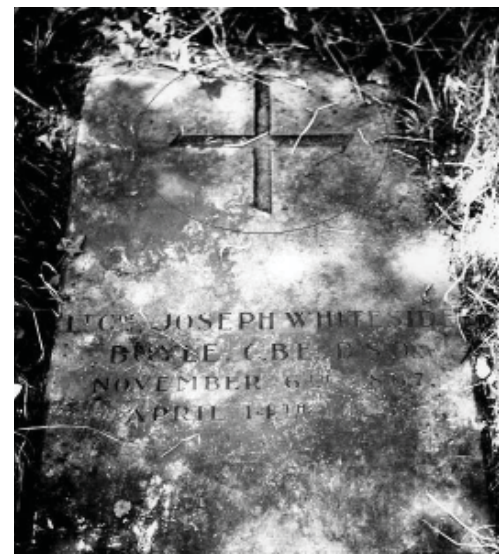

Fig. 78. A (red) circle drawn around the cross on the grave slab on Boyle's grave is to indicate that this is an image of the Order of Queen Maria Cross. Boyle's honorary rank is correct but the addition of $\mathrm{CBE}$ remains a mystery. www.woodstock.library.on.ca

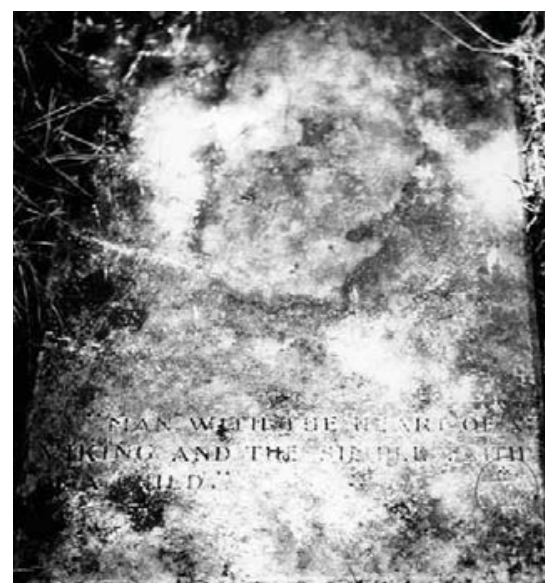


they were put away, according to Joe Jr., for safekeeping. One can only guess where the uniforms, awards, and other important papers of Boyle may be today. It can be said that one of our nation's greatest heroes was Joseph Whiteside Boyle, Duke of Jassy, Saviour of Romania, King of the Klondike.

\section{Conclusion}

Collecting military memorabilia serves as a reminder of sacrifices made by the soldiers who represented the Yukon. These military files, and the badges and medals worn by soldiers, are a true connection with the past. I hope I have shed a light on a historic subject that is often unknown to the general public.

\section{Author}

Timothy Popp is an independent historian affiliated with the Military Collectors Club of Canada and the Order and Medals Research Society; he is advisory committee vice-chairman for the Fred Light Museum in Battleford, Saskatchewan.

\section{References}

Abbink, Harry and Cindy, The Military Medal Canadian Recipients, 1916-1922, Calgary, Alberta, Alison Publishing Company, 1987.

Black, Martha Louise, My Ninety Years, Anchorage, Alaska, Alaska Northwest Publishing Company, 1976.

Blatherwick, F.J. Surgeon Commander, C.M., C.D., M.D., Canadian Orders, Decorations and Medals, Fifth Edition, Toronto, Ontario, The Unitrade Press, 2003.

Blatherwick, John, Surgeon Commander, C.M., C.D., M.D., Canadian Knighthoods, New Westminster, British Columbia, FJB Air Publications, 1996.

Cross, W.K., The Charlton Standard Catalogue of First World War Canadian Corps Badges, First Edition, Toronto, Ontario, Charlton Press, 1991.

Edwards, Ron, Personal research notes, photographs, and information courtesy of the late Ron Edwards, Powell River, British Columbia.

Foote, Isabel, In Praise of a Canadian Hero, Joseph Whiteside Boyle, Woodstock, Ontario, Joe Boyle Repatriation Committee Inc., 1983.

Greene, Ronald, "Jacoby Bros. Ltd., Manufacturing Jewellers," Journal of the British Columbia Historical Federation, Winter 2010, Vol. 43 No. 4.

Hamilton, Walter R., The Yukon Story, Vancouver, British Columbia, Mitchell Press, 1964. 
Harper, Joseph H., A Source of Pride, Badges of the Canadian Expeditionary Force 1914-1919, Ottawa, Ontario, Service Publications, 1999.

Joynt, Kevin, Worthy Investments, Canadians Decorated by the King, 1915-1919, Ottawa, Ontario, 1998.

Popp, Timothy, Personal research notes, photographs, and information from Timothy Popp's personal collection.

Riddle, David K. and Donald G. Marshall, The Distinguished Service Order Awarded to Members of the Canadian Expeditionary Force and Canadians in the Royal Naval Air Service, The Royal Flying Corps and Royal Air Force 1915-1920, Winnipeg, Manitoba, Kirkby-Marlton Press, 1991.

Riddle, David K. and Donald G. Marshall, The Military Cross Awarded to Members of the Canadian Expeditionary Force 1915-1921, Winnipeg, Manitoba, KirkbyMarlton Press, 1991.

Riddle, David K. and Donald G. Marshall, The Distinguished Conduct Medal Awarded to Members of the Canadian Expeditionary Force 1914-1920, Winnipeg, Manitoba, Kirkby-Marlton Press, 1991.

Rodney, William, Joe Boyle, King of the Klondike, Toronto, Ontario, McGraw-Hill Ryerson Limited, 1974.

Rosen, Albert and Peter Martin, Canadian Expeditionary Force Military Cap Badges Of World War 1, Toronto, Ontario, Romar Distributing Company, 1985.

Sauerwien, Stan, Klondike Joe Boyle, Heroic Adventures from Gold Fields to Battlefields, Canmore, Alberta, Altitude Publishing Canada Limited, 2003.

Taylor, Leonard W., The Sourdough and the Queen, The Many Lives of Klondike Boyle, Toronto, Ontario, Methuen Publications, 1983.

Taylor, Leonard, Worth Their Weight, Legion Magazine, July/August 1990.

Wallace, Jim (Editor), Canadian Foreign Awards, Awards to Nursing Service, Mention in Despatches World War 1 (1914-1919), Calgary, Alberta, Bunker to Bunker Publishing, 2001.

Wallace, Paul Ed Paquette, and Chris Enslen, The Meritorious Service Medal to Canadians, Including Awards to the Canadian Expeditionary Force 1916-1921, Medicine Hat, Alberta, Dusty Hat Publishing Company Limited, 2009.

Wigney, Edward H. (Compiled and Edited), Serial Numbers of the CEF, Nepean, Ontario, 1996.

Wigney, Edward H., Mentioned in Despatches, Nepean, Ontario, 2000.

Library \& Archives of Canada, Joseph Whiteside Boyle file, NA-A-98/0325-0332, Ottawa, Ontario.

Yukon Archives, George Black Collection, Whitehorse, Yukon Territory.

Yukon Archives, M. Waddington Collection, Whitehorse, Yukon Territory. 